Provided for non-commercial research and education use. Not for reproduction, distribution or commercial use.

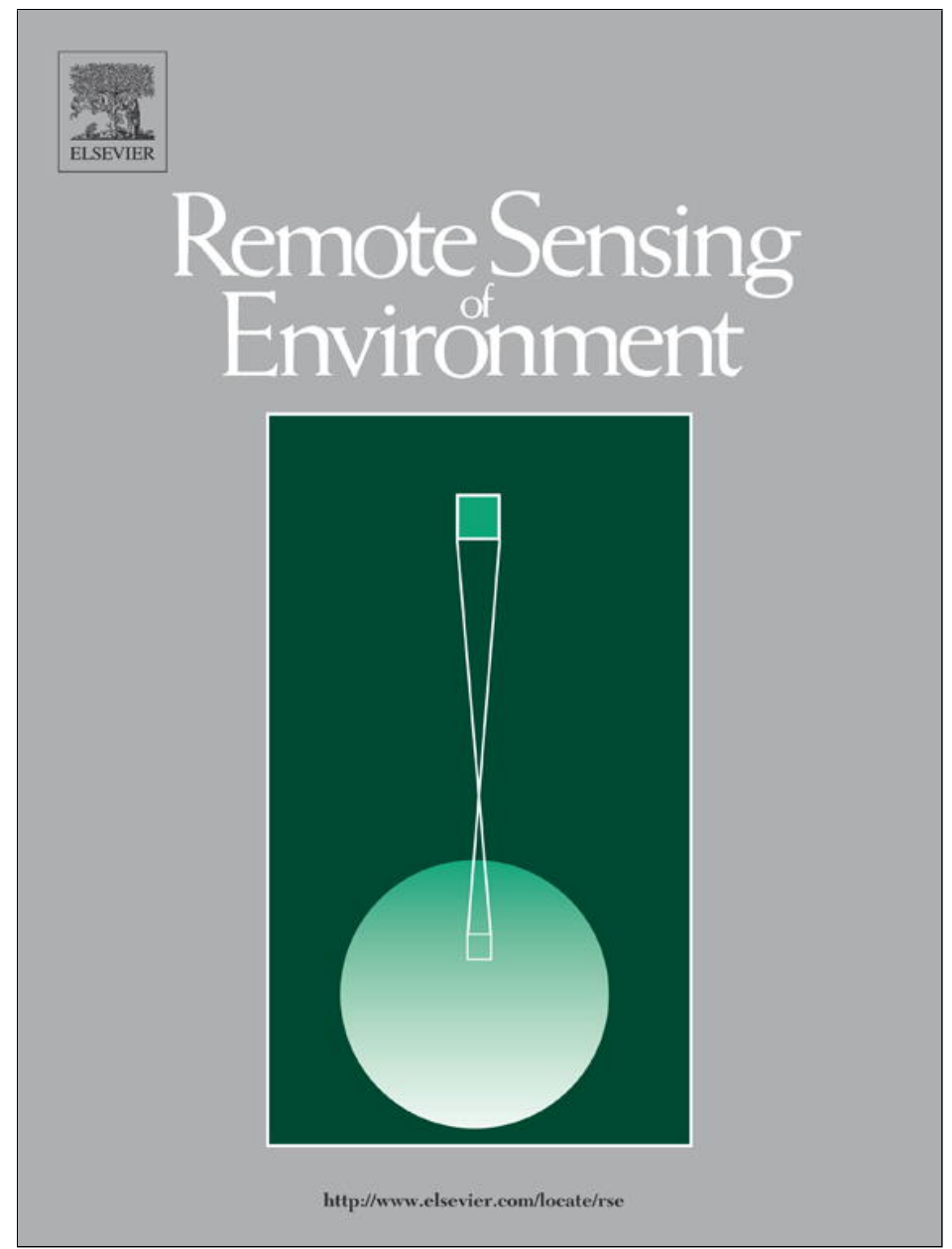

This article appeared in a journal published by Elsevier. The attached copy is furnished to the author for internal non-commercial research and education use, including for instruction at the authors institution and sharing with colleagues.

Other uses, including reproduction and distribution, or selling or licensing copies, or posting to personal, institutional or third party websites are prohibited.

In most cases authors are permitted to post their version of the article (e.g. in Word or Tex form) to their personal website or institutional repository. Authors requiring further information regarding Elsevier's archiving and manuscript policies are encouraged to visit:

http://www.elsevier.com/authorsrights 


\title{
Light absorption properties of southeastern Bering Sea waters: Analysis, parameterization and implications for remote sensing
}

\author{
Puneeta Naik ${ }^{\text {a }}$, Eurico J. D'Sa ${ }^{\text {a,* }}$, Helga do R. Gomes ${ }^{\text {b }}$, Joaquim I. Goés ${ }^{\text {b }}$, Colleen B. Mouw ${ }^{\text {c }}$ \\ a Louisiana State University, Department of Oceanography \& Coastal Sciences, Baton Rouge, LA, USA \\ ${ }^{\mathrm{b}}$ Lamont-Doherty Earth Observatory, 7 Marine Biology, Palisades, NY, USA \\ ${ }^{c}$ Dept. of Geological E Mining Engineering E Sciences, Michigan Technological University, Houghton, MI, USA
}

\section{A R T I C L E I N F O}

\section{Article history:}

Received 17 July 2012

Received in revised form 25 February 2013

Accepted 2 March 2013

Available online $\mathrm{xxxx}$

\section{Keywords:}

Bering Sea

Light absorption

Phytoplankton

Marine optics

Remote Sensing

Ocean Color

\begin{abstract}
A B S T R A C T
The absorption coefficients of phytoplankton $\left(\mathrm{a}_{\mathrm{PHY}}(\lambda)\right)$, non-algal particles (NAP) $\left(\mathrm{a}_{\mathrm{NAP}}(\lambda)\right)$ and colored dissolved organic matter $(\mathrm{CDOM})\left(\mathrm{a}_{\mathrm{CDOM}}(\lambda)\right)$ were investigated and parameterized in the southeastern Bering Sea during July 2008. The absorption coefficients were well structured with respect to hydrographic and biogeochemical characteristics of the shelf. The highest values of $\mathrm{a}_{\mathrm{PHY}}(443)$ were observed offshore and the lowest values of $\mathrm{a}_{\mathrm{PHY}}(443)$ were found in the coastal domain, a low productivity region associated with limited macronutrients. Values of $\mathrm{a}_{\mathrm{DG}}(\lambda)\left(\mathrm{a}_{\mathrm{CDOM}}(\lambda)+\mathrm{a}_{\mathrm{NAP}}(\lambda)\right)$ revealed an east-west gradient pattern with higher values in the coastal domain, and lower values in the outer domain. Lower chlorophyll specific $\mathrm{a}_{\mathrm{PHY}}(\lambda)\left(\mathrm{a}_{\mathrm{PHY}}^{*}(\lambda)\right)$ observed relative to middle and lower latitude waters indicated a change in pigment composition and/or package effect, which was consistent with phytoplankton community structure. $\mathrm{a}_{\mathrm{CDOM}}(\lambda)$ was the dominant light absorbing coefficient at all wavelengths examined except at $676 \mathrm{~nm}$. Modeling of remote-sensing reflectance $\left(\mathrm{R}_{\mathrm{rs}}(\lambda)\right)$ and the diffuse attenuation coefficient $\left(\mathrm{K}_{\mathrm{d}}(\lambda)\right)$ from inherent optical properties revealed the strong influence of $\mathrm{a}_{\mathrm{CDOM}}(\lambda)$ on $\mathrm{R}_{\mathrm{rs}}(\lambda)$ and $\mathrm{K}_{\mathrm{d}}(\lambda)$. Good optical closure was achieved between modeled and radiometer measured $\mathrm{R}_{\mathrm{rs}}(\lambda)$ and $\mathrm{K}_{\mathrm{d}}(\lambda)$ with average percent difference of less than $25 \%$ and $19 \%$ respectively, except at red wavelengths. The $\mathrm{a}_{\mathrm{CDOM}}(\lambda)$ accounted for $>50 \%$ of $\mathrm{K}_{\mathrm{d}}(\lambda)$ which was vertically variable. Chlorophyll-a calculated by the NASA standard chlorophyll-a algorithm (0C4.v6) was overestimated due to higher $\mathrm{a}_{\mathrm{CDOM}}(\lambda)$ and underestimated due to lower $\mathrm{a}_{\mathrm{PHY}}^{*}(\lambda)$ at low and high concentrations of chlorophyll-a, respectively.
\end{abstract}

(c) 2013 Elsevier Inc. All rights reserved.

\section{Introduction}

The southeastern Bering Sea is one of the most productive marine ecosystems in the world and provides half of the commercial seafood caught in the United States (Sigler et al., 2010). As the Bering Sea ecosystem responds to variations in climate, its capacity to supply the resources on which national and local economies depend upon will possibly change (Grebmeier et al., 2006). Long-term monitoring is therefore critical for understanding and predicting changes in this ecosystem (Sigler et al., 2010). Ocean color remote sensing is an important tool to examine changes in the southeastern Bering Sea ecosystem relative to in-situ observations in terms of spatial and temporal resolution. Apart from chlorophyll-a concentrations, ocean color sensors offer the potential to estimate other important variables, such as water column primary productivity (PP) and phytoplankton

\footnotetext{
* Corresponding author. Tel.: +1 225578 0212; fax: +1 2255782520

E-mail addresses: pnaik2@tigers.Isu.edu (P. Naik), ejdsa@lsu.edu (E.J. D’Sa), helga@Ideo.columbia.edu (H.R. Gomes), jig@Ideo.columbia.edu (J.I. Goés), cbmouw@mtu.edu (C.B. Mouw).
}

functional groups (McClain, 2009), which are essential for understanding long-term changes occurring in the Bering Sea ecosystem. Accurate estimates of these variables from space-based sensors require a thorough understanding of in-water optical properties. Despite the importance of the southeastern Bering Sea ecosystem as a biologically rich resource region, its optical properties have not been documented in detail and hence satellite-based estimates of phytoplankton biomass distribution have been confounded with uncertainty. Satellite-based patterns of phytoplankton variability in relation to ice edges and polar frontal regions have been described for the Bering Sea (Maynard \& Clark, 1987; Müller-Karger et al., 1990). Previous studies suggest that Coastal Zone Color Scanner (CZCS) pigment concentrations derived for the Bering Sea using global ocean color algorithms are lower than in-situ estimates (Maynard \& Clark, 1987). More recent studies have demonstrated that chlorophyll-a was overestimated by SeaWiFS OC2 algorithm in the Bering Sea (Schallenberg et al., 2008). The explanation for such biases in the Bering Sea and polar regions have been attributed to lower specific phytoplankton absorption, high CDOM and lack of adequate data for development of ocean color algorithms (Cota et al., 2003; Matsuoka et al., 2007; Stramska et al., 2006; Wang et al., 2005). 
Light absorption coefficients of phytoplankton, non-algal particles (NAP), and colored dissolved organic matter (CDOM) are major parameters that determine the optical variability of oceanic waters and hence an understanding of their variations with respect to environmental variability and ecological factors is fundamental to fine-tuning of bio-optical models. The absorption of light by particulate and dissolved matter significantly affect the variance of both remote-sensing reflectance $\left(R_{r s}(\lambda)\right)$ and the diffuse attenuation coefficient $\left(K_{d}(\lambda)\right)$. The total absorption coefficient of seawater is the sum of individual components within the water column, namely pure water, CDOM, phytoplankton and NAP and can be expressed as:

$\mathrm{a}_{\mathrm{T}}(\lambda)=\mathrm{a}_{\mathrm{W}}(\lambda)+\mathrm{a}_{\mathrm{CDOM}}(\lambda)+\mathrm{a}_{\mathrm{PHY}}(\lambda)+\mathrm{a}_{\mathrm{NAP}}(\lambda)$

$\mathrm{a}_{\mathrm{P}}(\lambda)=\mathrm{a}_{\mathrm{PHY}}(\lambda)+\mathrm{a}_{\mathrm{NAP}}(\lambda)$

$\mathrm{a}_{\mathrm{DG}}(\lambda)=\mathrm{a}_{\mathrm{CDOM}}(\lambda)+\mathrm{a}_{\mathrm{NAP}}(\lambda)$

where $a_{W}(\lambda), a_{C D O M}(\lambda), a_{P H Y}(\lambda), a_{N A P}(\lambda), a_{P}(\lambda)$ and $a_{D G}(\lambda)$ are absorption coefficients due to pure water, CDOM, phytoplankton, NAP, total particulate matter and CDOM plus NAP matter, respectively (see Table 1 for symbols used in this paper).

The absorption properties of high northern latitude regions (Cota et al., 2003; Matsuoka et al., 2011, 2007; Stramska et al., 2006; Wang et al., 2005), particularly the southeastern Bering Sea (Naik et al., 2010), have only recently been studied in detail. Due to large biases observed in retrievals of chlorophyll-a in the Arctic, region and season specific algorithms have been proposed with regional parameterization (Stramska et al., 2006) involving in-situ inherent optical properties (IOP's e.g. absorption, backscattering), apparent optical properties (AOP's e.g. normalized water leaving radiance, $\mathrm{R}_{\mathrm{rs}}(\lambda)$ ) and chlorophyll-a. Even if regional or seasonal empirical algorithms developed specifically for the higher latitudes are used, biases would likely exist due to the diverse nature of IOP's in these regions. One such example is the Arctic OC4L (Cota et al., 2004) which performed less satisfactorily in the western Arctic when highly turbid waters were included (Matsuoka et al., 2007). A preferential approach

Table 1

Table of Symbols

\begin{tabular}{|c|c|}
\hline Symbol & Description \\
\hline $\mathrm{a}_{\mathrm{PHY}}(\lambda)$ & Phytoplankton absorption coefficient $\left(\mathrm{m}^{-1}\right)$ \\
\hline$a_{p}(\lambda)$ & Particulate absorption coefficient $\left(\mathrm{a}_{\mathrm{PHY}}(\lambda)+\mathrm{a}_{\mathrm{NAP}}(\lambda)\right)\left(\mathrm{m}^{-1}\right)$ \\
\hline $\mathrm{a}_{\mathrm{PHY}}^{*}(\lambda)$ & Chlorophyll-a specific phytoplankton absorption $\left.\left(\mathrm{m}^{2}(\mathrm{mg} \mathrm{chl} a)^{-1}\right)\right)$ \\
\hline $\mathrm{a}_{\mathrm{CDOM}}(\lambda)$ & CDOM absorption coefficient $\left(\mathrm{m}^{-1}\right)$ \\
\hline $\mathrm{a}_{\mathrm{DG}}(\lambda)$ & $\begin{array}{l}\text { Spectral absorption coefficient for non-algal particulate } \\
\text { matter }+ \text { CDOM }\left(\mathrm{m}^{-1}\right)\end{array}$ \\
\hline $\mathrm{a}_{\mathrm{NAP}}(\lambda)$ & Non-algal particulate matter (NAP) absorption coefficient $\left(\mathrm{m}^{-1}\right)$ \\
\hline $\mathrm{a}_{\mathrm{T}-\mathrm{CDOM}}(\lambda)$ & Total water absorption minus $\mathrm{a}_{\mathrm{CDOM}}(\lambda)\left(\mathrm{m}^{-1}\right)$ \\
\hline$a_{T}-w(\lambda)$ & Total absorption coefficient minus absorption by pure sea-water $\left(\mathrm{m}^{-1}\right)$ \\
\hline $\mathrm{a}_{\mathrm{T}}(\lambda)$ & Total absorption coefficient $\left(\mathrm{m}^{-1}\right)$ \\
\hline$a_{w}(\lambda)$ & Absorption coefficient of pure water $\left(\mathrm{m}^{-1}\right)$ \\
\hline B & Backscattering ratio treated as constant (dimensionless) \\
\hline$b_{b}(\lambda)$ & Total backscattering coefficient $\left(\mathrm{m}^{-1}\right)$ \\
\hline$b_{p}(\lambda)$ & Particulate scattering coefficient $\left(\mathrm{m}^{-1}\right)$ \\
\hline$b_{W}(\lambda)$ & Scattering coefficient of pure sea water $\left(\mathrm{m}^{-1}\right)$ \\
\hline$b(\lambda)$ & Total scattering coefficient $\left(\mathrm{m}^{-1}\right)$ \\
\hline$E_{d}(\lambda)$ & In-water downwelling irradiance $\left(\mathrm{W} \mathrm{m}^{-2} \mathrm{~nm}^{-1}\right)$ \\
\hline$K_{d}(\lambda)$ & Diffuse attenuation coefficient of downwelling irradiance $\left(\mathrm{m}^{-1}\right)$ \\
\hline $\mathrm{L}_{\mathrm{u}}(\lambda)$ & In-water upwelling radiance $\left(\mathrm{W} \mathrm{m}-2 \mathrm{~nm}^{-1} \mathrm{sr}^{-1}\right)$ \\
\hline $\mathrm{R}_{\mathrm{rs}}(\lambda)$ & Remote sensing reflectance $\left(\mathrm{sr}^{-1}\right)$ \\
\hline $\mathrm{S}_{\mathrm{CDOM}}$ & Spectral slope of CDOM absorption coefficient $\left(\mathrm{nm}^{-1}\right)$ \\
\hline $\mathrm{S}_{\mathrm{DG}}$ & Spectral slope of CDOM plus NAP absorption coefficient $\left(\mathrm{nm}^{-1}\right)$ \\
\hline $\mathrm{S}_{\mathrm{f}}$ & Size fraction of small and large phytoplankton cells ( 0 to 1 ) (dimensionless) \\
\hline$S_{\text {NAP }}$ & Spectral slope of NAP absorption coefficient $\left(\mathrm{nm}^{-1}\right)$ \\
\hline$\beta$ & Pathlength amplification factor (dimensionless) \\
\hline$\lambda$ & Wavelength (nm) \\
\hline$\lambda_{0}$ & Reference wavelength ( $\mathrm{nm}$ ) \\
\hline$\mu_{\mathrm{d}}$ & cosine of the mean downwelling light field \\
\hline
\end{tabular}

would be to use semi-analytical algorithms that are based on the relationship between remote sensing reflectance $\left(\mathrm{R}_{\mathrm{rs}}(\lambda)\right)$ and IOPs. Recent studies (Naik et al., 2010) have shown the potential of the Quasi Analytical Algorithm (QAA) (Lee et al., 2002) to retrieve absorption coefficients in the southeastern Bering Sea. The development or regional parameterization of empirical or semi-analytical ocean color algorithms and characterization of the bio-optical properties in the Bering Sea would require better understanding of the relationship between IOPs (absorption and scattering) and AOPs $\left(\mathrm{R}_{\mathrm{rs}}(\lambda)\right.$ and $\mathrm{K}_{\mathrm{d}}(\lambda)$ ).

The objectives of this study are to (1) describe the absorption budget and its spatial distribution across and along shelf transects at different depths, (2) describe $a^{*}{ }_{\text {PHY }}(\lambda)$ variability and parameterize the phytoplankton, CDOM plus NAP and total water minus pure water absorption coefficients using simple regression models, and (3) describe the influence of the absorption coefficients on $\mathrm{R}_{\mathrm{rs}}(\lambda)$ (hence estimates of chlorophyll-a from ocean color algorithms) and $K_{d}(\lambda)$.

\section{Methods and materials}

\subsection{Study area}

The Bering Sea is a semi-enclosed basin (Fig. 1) with an extensive continental shelf in the east, a steep shelf break and deep basin waters towards the west. During summer the southeastern Bering Sea shelf waters can be broadly classified into three domains based on frontal structures associated with wind, bathymetry and tides (Kachel et al., 2002), the coastal domain ( $<50 \mathrm{~m}$ depth) extending from the Alaskan coast to the inner front at $\sim 50 \mathrm{~m}$ isobath, the middle domain (50-100 $\mathrm{m}$ depth) extending from the inner front to the central front at $\sim 100 \mathrm{~m}$ isobath, and the outer domain (100-200 m depth) extending from the central front to the shelf break.

The general circulation in the Bering Sea is part of the North Pacific sub-arctic gyre with advection of Pacific water from the Aleutian Stream through the various passes along the Aleutian Islands with net outflow into the Arctic through the Bering Strait (Schumacher \& Stabeno, 1998). Most of the shelf circulation is characterized by diffuse flows to the north following the bathymetry with tidal energy dominating most of the shelf. The hydrographic structure of the northern shelf is driven by salinity whereas the southern shelf is driven by temperature. Sea ice melt is the primary source of freshwater that influences the central and outer domains (Aguilar-Islas et al., 2008). Apart from ice melt, the Bering shelf receives large volumes of freshwater input from the Yukon and Kuskokwim rivers. The Yukon River has the fifth largest drainage basin in North America and discharges an annual average of $\sim 200 \mathrm{~km}^{3}$ freshwater to the northern Bering shelf (Stabeno et al., 2006) while Kuskokwim has a much smaller drainage basin delivering $~ 34 \mathrm{~km}^{3}$ of freshwater to the southern and eastern parts of the Bering Sea (Feely et al., 1981). The maximum discharge occurs during the peak ice melt in May and June with a small pulse in August. Although the runoff from both the rivers is constrained to the coast by strong inner shore currents, the Kuskokwim River has a greater influence on our study region as the runoff flows along the coast with part of it diverging at the Nunivak islands along the shelf to north, driven mainly by winds and tidal currents (Fig. 1). The influence of river runoff is significant on the vertical structure of the coastal domain where it combines with shelf waters forming the low salinity water mass known as the Alaskan Coastal waters (ACW) (Coachman, 1986). The signature of ACW is also found in the Arctic waters (Chukchi Sea), transporting high concentration of CDOM to the western Arctic Ocean (Matsuoka et al., 2011).

\subsection{Discrete water sampling}

Station locations that were sampled are shown in Fig. 1. Physical and biological measurements, and water sampling were conducted along and across shelf transects covering the coastal, middle and 


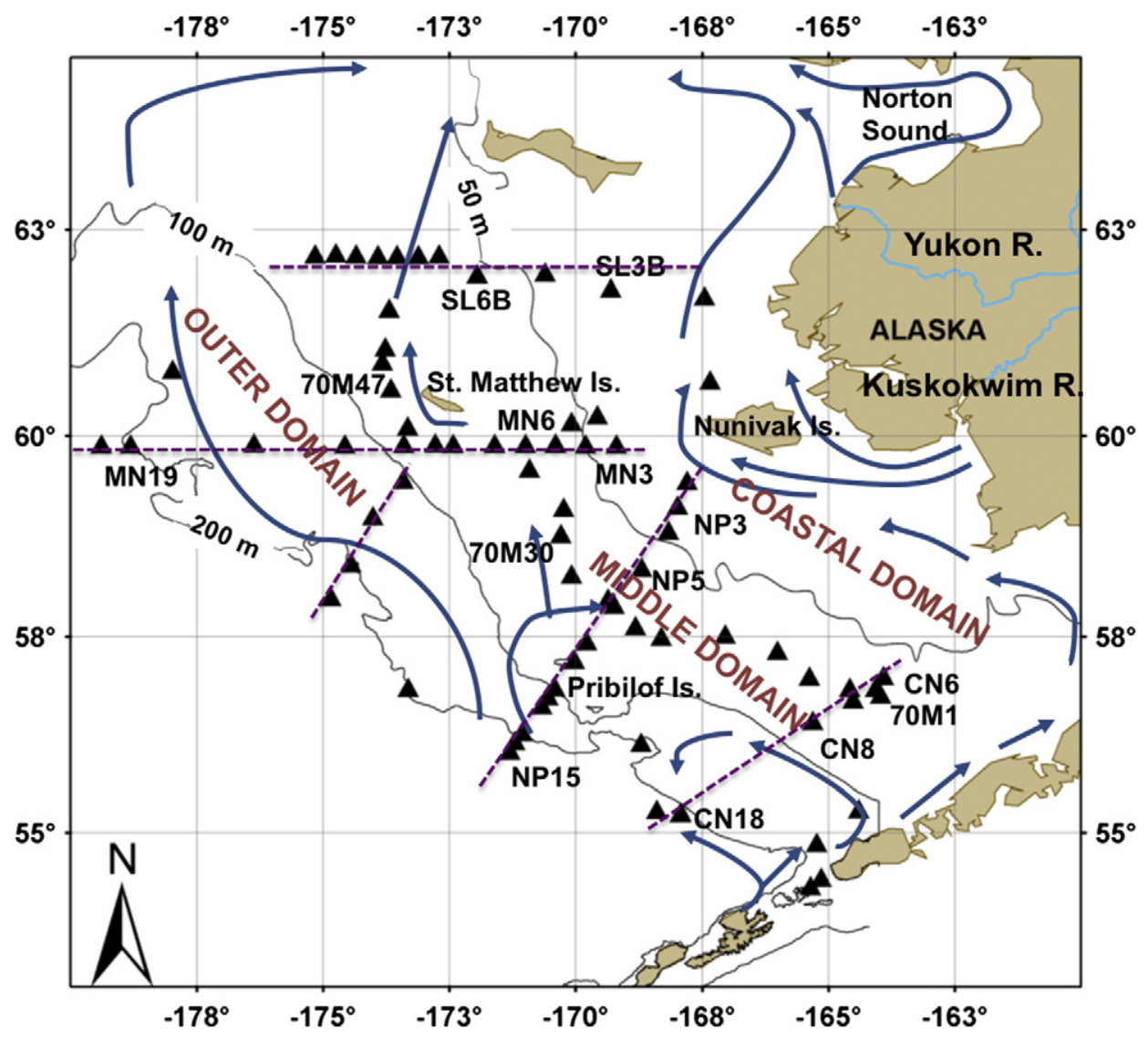

Fig. 1. Station map showing station locations (black triangles) covered during a cruise in July 2008. The general circulation (blue arrows) is from Stabeno et al. (2006). The Coastal Domain, Middle Domain and Outer Domain are also shown.

outer domains during a cruise on the USCGC Healy in July 2008. The Bering Sea was ice-free during the entire cruise. At every station, salinity, temperature and density profiles were recorded with a SeaBird SBE-911 plus CTD unit and water samples were collected for absorption analyses at 3 depths (or more) - surface, middle 1 and middle 2 using Niskin bottles attached to the CTD. The middle 1 depth corresponded to the chlorophyll fluorescence maximum depth if it was present at the station, while middle 2 depth was a few meters below the chlorophyll fluorescence maximum depth.

\subsubsection{Particulate absorption and chlorophyll-a measurements}

Particulate absorption measurements were made following the standard quantitative filter technique (QFT) procedure (Mitchell, 1990). Discrete water samples were filtered immediately after collection under low vacuum on $0.7 \mu \mathrm{m}$ Whatman GF/F glass fiber filters and stored in liquid nitrogen until analysis for particulate absorption and chlorophyll-a. Chlorophyll-a concentration was determined fluorometrically with 90\% acetone (Holm-Hansen et al., 1965) in a Turner Designs fluorometer. The volume of water filtered was adjusted between water types so that sufficient particles were loaded on the filter without overloading the filter. The bulk of the particulate absorption measurements were carried out onboard and the remaining samples were frozen at $-80^{\circ} \mathrm{F}$ and brought back to the lab for analysis

In the case of the frozen samples, they were first thawed to room temperature after removing from liquid nitrogen by keeping them in the dark at room temperature for half an hour. Filter blanks were prepared by filtering $15 \mathrm{ml}$ of $0.2 \mu \mathrm{m}$ filtered seawater corresponding to the station and depth under analysis. Absorbance measurements of total particulate matter $\left(A_{P}(\lambda)\right)$ were done by scanning the sample filter using a shipboard WPI Ultrapath ${ }^{\mathrm{TM}}$ system (Ultrapath, WPI Inc.,
Sarasota, FL, USA) from 190 to $722 \mathrm{~nm}$ at $1 \mathrm{~nm}$ intervals. In laboratory studies the Ultrapath system showed good agreement with comparisons done on a dual beam Lambda 850 spectrophotometer equipped with an integrating sphere for both phytoplankton cell cultures as well as field samples from diverse oceanic regions (Naik \& D'Sa, 2012). To separate the phytoplankton pigments within the particulate matter from NAP, methanol extraction (1-4 h) was done (Kishino et al., 1985). The sample filter paper was scanned again to obtain non-algal particulate (NAP) absorbance $\left(\mathrm{A}_{\mathrm{NAP}}(\lambda)\right)$. To minimize the differences between sample and blank filters all the sample spectra were shifted to zero near the infra-red region by subtracting the average absorbance from 712 to $722 \mathrm{~nm}$. The optical densities were corrected for pathlength amplification using the Naik and D'Sa (2012) beta ( $\beta$ ) correction algorithm. The $\beta$ correction algorithm for Lambda 850 obtained for our study was similar to that obtained by Cleveland and Weidemann (1993), lower than that obtained by Mitchell (1990) and higher than that obtained by Bricaud and Stramski (1990). The accuracy of $a_{P}(\lambda)$ values taking into consideration the beta factor inconsistency and instrumental factors would be less than $20 \%$.

The absorbances corrected for pathlength amplification $\left(A_{P(\text { corr })}(\lambda)\right.$ or $\mathrm{A}_{\mathrm{NAP}(\mathrm{corr})}(\lambda)$ ) were converted to absorption coefficients using the equation:

$\mathrm{a}_{\mathrm{P} \text { or NAP }}(\lambda)=\frac{2.303\left\lfloor A_{\mathrm{P} \text { or NAP }(\text { corr })}(\lambda)\right\rfloor}{(V / A)}$

where $\mathrm{a}_{\mathrm{p}}(\lambda)\left(\mathrm{m}^{-1}\right)$ is the total particulate absorption and $\mathrm{a}_{\mathrm{NAP}}(\lambda)$ $\left(\mathrm{m}^{-1}\right)$ is the non-algal particulate absorption. The coefficient 2.303 is a factor for converting from base e to base 10 logarithm, $\mathrm{V}\left(\mathrm{m}^{3}\right)$ is the volume filtered, and $\mathrm{A}\left(\mathrm{m}^{2}\right)$ the filter paper clearance area. The 
phytoplankton absorption $\left(\mathrm{a}_{\mathrm{PHY}}(\lambda)\left(\mathrm{m}^{-1}\right)\right)$ spectra were obtained by subtracting the $\mathrm{a}_{\mathrm{NAP}}(\lambda)\left(\mathrm{m}^{-1}\right)$ from $\mathrm{a}_{\mathrm{P}}(\lambda)$ using the relation:

$\mathrm{a}_{\mathrm{PHY}}(\lambda)=\mathrm{a}_{\mathrm{P}}(\lambda)-\mathrm{a}_{\mathrm{NAP}}(\lambda)$

The $\mathrm{a}_{\mathrm{NAP}}(\lambda)$ spectra can be expressed by an exponential function:

$\mathrm{a}_{\mathrm{NAP}}(\lambda)=\mathrm{a}_{\mathrm{NAP}}\left(\lambda_{0}\right) e^{\left(-S_{\mathrm{NAP}}\left(\lambda-\lambda_{0}\right)\right)}$

The wavelength $\lambda_{0}(443 \mathrm{~nm})$ is the reference wavelength in this study and $S_{\text {NAP }}$ represents the spectral slope for $a_{\text {NAP }}(\lambda)$. A non-linear least square fit (MATLAB®) was applied to calculate $S_{\mathrm{NAP}}$ from 350 to $700 \mathrm{~nm}$. Although residual absorption from inefficient removal of pigments through methanol extraction was not evident in $\mathrm{a}_{\mathrm{NAP}}(\lambda)$ spectra, we excluded the $400-480 \mathrm{~nm}$ and $620-700 \mathrm{~nm}$ ranges to avoid any residual pigment absorption that might still have been present (Babin et al., 2003).

Chlorophyll-a specific phytoplankton absorption $\left(a^{*}{ }_{\mathrm{PHY}}(\lambda)\right.$ $\left.\left(\mathrm{m}^{2}(\mathrm{mg} \mathrm{chl} a)^{-1}\right)\right)$ was obtained by dividing $\mathrm{a}_{\mathrm{PHY}}(\lambda)$ by chlorophyll-a $\left(\mathrm{mg} \mathrm{m}^{-3}\right.$ ). Regression analysis was conducted to determine the relationship between $\mathrm{a}_{\mathrm{PHY}}(\lambda)$ and chlorophyll-a from 400 to $700 \mathrm{~nm}$ at $2 \mathrm{~nm}$ intervals (Bricaud et al., 1998):

$\mathrm{a}_{\mathrm{PHY}}(\lambda)=\alpha_{\mathrm{CHL}}(\lambda)[\text { chlorophyl }-\mathrm{a}]^{\left(\beta_{\mathrm{CHL}}(\lambda)\right)}$

where, $\alpha_{\mathrm{CHL}}(\lambda)$ and $\beta_{\mathrm{CHL}}(\lambda)$ are the coefficients of the non-linear fit derived from our dataset.

For parameterization of $\mathrm{a}_{\mathrm{PHY}}(\lambda)$ and total absorption minus water $\left(a_{\mathrm{T}}-\mathrm{w}(\lambda)\right)$, the following relationships were used:

$\mathrm{a}_{\mathrm{PHY} \text { or T-W }}(\lambda)=\alpha_{\mathrm{PHY} \text { or T }-W}(\lambda)\left[\mathrm{a}_{\mathrm{PHY} \text { or T-W }}(443)\right]^{\left(\beta_{\text {PHY or T- } W}(\lambda)\right)}$

where, $\mathrm{a}_{\mathrm{PHY}}(443)$ and $\mathrm{a}_{\mathrm{T}}-\mathrm{w}(443)$ are the phytoplankton absorption and total absorption minus water absorption at $443 \mathrm{~nm}$ respectively, $\alpha_{\mathrm{PHY}}(\lambda), \beta_{\mathrm{PHY}}(\lambda)$ and $\alpha_{\mathrm{T}}-\mathrm{w}(\lambda), \beta_{\mathrm{T}}-\mathrm{w}(\lambda)$ are the coefficients of non-linear regression derived for our dataset from $400-700 \mathrm{~nm}$ at $2 \mathrm{~nm}$ interval.

\subsubsection{CDOM absorption measurement}

For CDOM absorption $\left(\mathrm{a}_{\mathrm{CDOM}}(\lambda)\right)$, discrete water samples were filtered immediately after collection through $0.2 \mu \mathrm{m}$ nylon membrane filters under low vacuum. Most samples were immediately analyzed onboard and the remaining filtered samples were stored in acid cleaned, pre-combusted amber colored glass bottles and stored at $4{ }^{\circ} \mathrm{C}$. The filtered samples were allowed to reach ambient room temperature to minimize temperature bias between samples and blank. Absorbance measurements of $\operatorname{CDOM}\left(\mathrm{A}_{\mathrm{CDOM}}(\lambda)\right)$ were done on a shipboard WPI Ultrapath ${ }^{\mathrm{TM}}$ system from 190 to $722 \mathrm{~nm}$ at $1 \mathrm{~nm}$ intervals. The pathlength was variable (either $10 \mathrm{~cm}$ or $50 \mathrm{~cm}$ ) depending on whether significant absorbance was observed between 400 and $500 \mathrm{~nm}$. The sample cell was cleaned between measurements using successive rinses of Methanol, 10\% HCL and Milli-Q water. For the reference, salt solutions with refractive indices close to seawater samples were prepared using granular $\mathrm{NaCl}$ (Mallinckrodt) and Milli-Q water, to minimize the differences in refractive index between sample and reference, which can cause offsets in absorbance measurements (D'Sa et al., 1999).

The absorbance data were corrected for baseline fluctuations by subtraction of the mean value over $5 \mathrm{~nm}$ interval of the measured absorbance at $700 \mathrm{~nm}$ from each wavelength (Mitchell et al., 2003). The $\mathrm{a}_{\text {СDOM }}(\lambda)\left(\mathrm{m}^{-1}\right)$ for pathlength, $\mathrm{L}\left(\mathrm{m}^{-1}\right)$ was calculated according to:

$\mathrm{a}_{\mathrm{CDOM}}(\lambda)=\frac{2.303\left[A_{\mathrm{CDOM}}(\lambda)\right]}{(L)}$
Spectra of $\mathrm{a}_{\mathrm{CDOM}}(\lambda)$ can be expressed as an exponential function as follows:

$\mathrm{a}_{\mathrm{CDOM} \text { or DG }}(\lambda)=\mathrm{a}_{\mathrm{CDOM} \text { or DG }}\left(\lambda_{0}\right) e^{\left(-S_{\mathrm{CDOM} \text { or DG }}\left(\lambda-\lambda_{0}\right)\right)}$

where $\lambda_{0}$ is the reference wavelength chosen as $443 \mathrm{~nm}$, and $\mathrm{S}_{\mathrm{CDOM}}$ denotes the spectral slope for CDOM absorption. For each $\mathrm{a}_{\mathrm{CDOM}}(\lambda)$ spectra, $S_{\mathrm{CDOM}}$ was calculated by fitting a non-linear least square to an exponential function from 350-500 nm (Babin et al., 2003; Twardowski et al., 2004). Similarly, for CDOM plus NAP absorption $\left(\mathrm{a}_{\mathrm{DG}}(\lambda)\right)$, the spectral slope of CDOM plus NAP $\left(\mathrm{S}_{\mathrm{DG}}\right)$ was calculated by applying a non-linear least square fit to every $\mathrm{a}_{\mathrm{DG}}(\lambda)$ spectra from $350-550 \mathrm{~nm}$ with the exclusion of the 400-480 nm range (Babin et al., 2003).

\subsection{Bio-optical package measurements}

Two profiling bio-optical packages (BOP) were utilized during the cruise. For the first half of the cruise, the BOP consisted of a hyperspectral absorption and attenuation meter (ac-s, WETLabs), a three angle $\left(100^{\circ}, 125^{\circ}\right.$, and $\left.150^{\circ}\right)$, three wavelength $(470 \mathrm{~nm}, 530 \mathrm{~nm}$, and $660 \mathrm{~nm}$ ) backscattering meter (ECO VSF3, WETLabs), a CTD (SBE-19, Seabird) and hyperspectral downwelling spectral irradiance and upwelling spectral radiance meter (HyperOCR, Satlantic). For the second half of the cruise the BOP consisted of hyperspectral absorption and attenuation meter (ac-s, WETLabs), a nine wavelength $(412 \mathrm{~nm}, 440 \mathrm{~nm}, 488 \mathrm{~nm}, 510 \mathrm{~nm}, 532 \mathrm{~nm}, 595 \mathrm{~nm}, 660 \mathrm{~nm}$, $676 \mathrm{~nm}$, and $715 \mathrm{~nm}$ ), one angle $\left(117^{\circ}\right)$ backscattering meter (ECO BB9, WETLabs) and a CTD. An SPMR (SeaWiFS Profiling Multichannel Radiometer, Satlantic) was used for measurements of downwelling spectral irradiance and upwelling spectral radiance during the second half of the cruise and was deployed immediately after the BOP profiling. Time-stamped data from instruments on the BOP were aligned to the CTD data and vertical profiles were binned at $0.5 \mathrm{~m}$ depth intervals.

The ac-s data were corrected for temperature, salinity, and scattering (Pegau et al., 1997; Zaneveld et al., 1994) using optically clean Milli-Q water as a reference (obtained from the calibration of the ac-s multiple times during the cruise). The total scattering coefficient $\left(\mathrm{b}_{(\mathrm{ac}-\mathrm{s})}\left(\mathrm{m}^{-1}\right)\right)$ was calculated as the difference between corrected absorption $\left(\mathrm{a}_{\mathrm{T}(\mathrm{ac}-\mathrm{s})}\left(\mathrm{m}^{-1}\right)\right)$ and attenuation coefficient. The backscattering data were corrected for salinity and light loss due to absorption over the path length at each angle and wavelength using the ac-s derived absorption and scattering values (Boss et al., 2004). The corrected backscattering coefficients $\left(\mathrm{b}_{\mathrm{b}}(\lambda)\left(\mathrm{m}^{-1}\right)\right)$ obtained are sum of particulate backscattering and backscattering by pure water.

The irradiance and radiance data from SPMR and HyperOCR were processed using Prosoft 7.7.16 (Satlantic). Radiometer $\mathrm{R}_{\mathrm{rs}}(\lambda)\left(\mathrm{sr}^{-1}\right)$ was calculated as ratio of upwelling radiance $\left(L_{u}(\lambda)\right)$ and downwelling irradiance $\left(E_{d}(\lambda)\right)$ just above the sea surface. A 5-point moving linear regression of $\ln E_{d}(\lambda)$ versus depth was used to obtain diffuse attenuation coefficient for downwelling irradiance $\left(\mathrm{K}_{\mathrm{d}}(\lambda)\right)\left(\mathrm{m}^{-1}\right)$. To calculate the $L_{u}(\lambda)$ and $E_{d}(\lambda)$ just above the sea surface, values of $K_{d}(\lambda)$ at shallowest depth were used to first calculate $L_{u}(\lambda)$ and $E_{d}(\lambda)$ just below the sea surface. These values were then extrapolated to values just above the surface based on Fresnel reflectance at air-water interface for $L_{u}(\lambda)$ and $E_{d}(\lambda)$ (Mueller \& Austin, 1995). As the performance of Medium Resolution Imaging Spectrometer (MERIS) in the study area has been found to be reasonable (Naik et al., 2010), $R_{\mathrm{rS}}(\lambda)$ was also obtained from MERIS Level 2 data (http://merci-srv.eo.esa.int/merci/) using a $3 \times 3$ pixel box size ( $1.2 \mathrm{~km} /$ pixel for MERIS) with a time difference of $\pm 8 \mathrm{~h}$ between the in-situ sampling and satellite overpass.

2.4. Modeling of remote sensing reflectance $\left(R_{r s}(\lambda)\right)$ and diffuse attenuation coefficient for downwelling irradiance $\left(K_{d}(\lambda)\right)$

The influence of absorption coefficients on $\mathrm{R}_{\mathrm{rs}}(\lambda)$ and $\mathrm{K}_{\mathrm{d}}(\lambda)$ were assessed by modeling these quantities (i) using in-situ absorption 
coefficients (discrete and continuous profile) and backscattering coefficients (modeled and continuous profile), and (ii) by excluding $\mathrm{a}_{\text {CDOM }}(\lambda)$ from $\mathrm{a}_{\mathrm{T}}(\lambda)$ to show the effect of $\mathrm{a}_{\mathrm{CDOM}}(\lambda)$. The validity of the modeled $\mathrm{R}_{\mathrm{rs}}(\lambda)$ and $\mathrm{K}_{\mathrm{d}}(\lambda)$ were tested by comparing them with in-situ radiometer derived $\mathrm{R}_{\mathrm{rS}}(\lambda)$ and $\mathrm{K}_{\mathrm{d}}(\lambda)$. The details on the modeling process are described below.

$\mathrm{R}_{\mathrm{rs}}(\lambda)$ at the surface was modeled through IOPs according to the equations shown below (Gordon et al., 1988; Mobley, 1994):

$R_{\mathrm{rs}(\mathrm{DM})}(\lambda) \approx 0.54(f / Q)\left[\frac{b_{b(\text { model })}(\lambda)}{\mathrm{a}_{T}(\lambda)+b_{b(\text { model })}(\lambda)}\right]$

$R_{\mathrm{rs}(\mathrm{BM})}(\lambda) \approx 0.54(f / Q)\left[\frac{b_{b(\mathrm{ECO})}(\lambda)}{\mathrm{a}_{T(\mathrm{ac}-s)}(\lambda)+b_{b(\mathrm{ECO})}(\lambda)}\right]$

where the value of 0.54 accounts for the Fresnel reflectivity at the sea surface, $\mathrm{f} / \mathrm{Q}$ ratio was determined by dividing 0.54 by the slope obtained from linear regression of $\mathrm{b}_{\mathrm{b}(\mathrm{ECO})}(\lambda) /\left(\mathrm{a}_{\mathrm{T}(\mathrm{ac}-\mathrm{s})}(\lambda)+\mathrm{b}_{\mathrm{b}(\mathrm{ECO})}(\lambda)\right)$ and $\mathrm{R}_{\mathrm{rS}}(\lambda)$ obtained from BOP. The $\mathrm{f} / \mathrm{Q}$ values ranged from 0.092 to $0.11\left(\mathrm{r}^{2}\right.$ ranged from 0.80 to 0.94 ) for wavelengths between $400 \mathrm{~nm}$ to $680 \mathrm{~nm}$. For all the wavelengths taken together the $f / Q$ value was $0.096\left(r^{2}=0.87\right.$, $\mathrm{n}=96) . \mathrm{R}_{\mathrm{rs}(\mathrm{DM})}(\lambda)$ is $\mathrm{R}_{\mathrm{rs}}(\lambda)$ modeled from discrete measurements of absorption and modeled backscattering ( $b_{b(\text { model })}(\lambda)$ - Eq. (14)). $\mathrm{R}_{\mathrm{rs}(\mathrm{DM}-\mathrm{CDOM})}(\lambda)$ (Fig. 8b) is $\mathrm{R}_{\mathrm{rs}}(\lambda)$ modeled from discrete measurements of absorption without contribution from CDOM and modeled backscattering. $\mathrm{R}_{\mathrm{rS}(\mathrm{BM})}(\lambda)$ is $\mathrm{R}_{\mathrm{rS}}(\lambda)$ modeled from IOPs measured with the BOP. $\mathrm{a}_{\mathrm{T}}(\lambda)$ is total water absorption coefficient obtained from discrete water measurements and $\mathrm{a}_{\mathrm{T}(\mathrm{ac}-\mathrm{s})}(\lambda)$ is total water absorption coefficient from ac-s. $b_{b(E C O)}(\lambda)$ is the backscattering coefficient obtained from backscattering meter (ECO VSF3 or ECO BB9) on the BOP. $\mathrm{b}_{\mathrm{b}(\text { model })}(\lambda)$ is backscattering modeled as (Morel \& Maritorena, 2001):

$b_{p}(\lambda)=0.416\left[\right.$ chlorophyl $\left.-a^{0.766}\right](550 / \lambda)$

$b_{b(\text { model })}(\lambda)=1 / 2 b_{w}(\lambda)+B b_{p}(\lambda)$

where $b_{p}(\lambda)$ is the particulate scattering coefficient, $b_{b}(\lambda)$ is the backscattering coefficient, $b_{w}(\lambda)$ is scattering by pure water and $B(=0.0183)$ is the backscattering ratio treated as constant (Gould et al., 1999).

$\mathrm{K}_{\mathrm{d}}(\lambda)$ was modeled through IOPs according to the equations given below (Aas, 1987):

$K_{d(\mathrm{DM})}(\lambda) \approx \frac{1}{\mu_{d}}\left[\mathrm{a}_{T}(\lambda)+b_{b(\text { model })}(\lambda)\right]$

$K_{d(\mathrm{BM})}(\lambda) \approx \frac{1}{\mu_{d}}\left[\mathrm{a}_{T(\mathrm{ac}-s)}(\lambda)+b_{b(\mathrm{ECO})}(\lambda)\right]$

where $\mu_{d}$ is the cosine of the mean downwelling light field. $K_{d(D M)}(\lambda)$ is $K_{d}(\lambda)$ modeled from discrete measurements of absorption and modeled scattering $\left(b_{b(\text { model })}(\lambda)-\right.$ Eq. (14)). $K_{d(B M)}(\lambda)$ is $K_{d}(\lambda)$ modeled from measurements of IOPs from BOP. $\mathrm{K}_{\mathrm{d}(\mathrm{DM}-\mathrm{CDOM})}(\lambda)$ (Fig. 8d) is $\mathrm{K}_{\mathrm{d}}(\lambda)$ modeled from discrete measurements of absorption without contribution from CDOM and modeled scattering. $\mu_{\mathrm{d}}$ was determined as the slope of the linear fit between $\mathrm{a}_{\mathrm{T}(\mathrm{ac}-\mathrm{s})}(\lambda)+$ $b_{b(E C O)}(\lambda)$ and $K_{d}(\lambda)$ obtained from BOP. Two values of $\mu_{d}$ corresponding to the surface and middle depth samples were determined and used in the above equations. The $\mu_{d}$ for the surface samples was $0.780 \pm$ $0.013\left(\mathrm{r}^{2}=0.81 ; \mathrm{n}=107\right)$ and for the middle depths was $0.631 \pm$ $0.013\left(r^{2}=0.72 ; n=97\right)$. $\mu_{d}$ has been shown to vary between 0.8 to 0.65 from the surface to $1 \%$ light for b/a ratio of 4 and solar zenith angle of $30^{\circ}$ (Bannister, 1974).

\section{Results and discussion}

\subsection{Absorption budget and its spatial distribution in relation to hydrographic and biogeochemical characteristics}

The hydrographic structure, nutrients, and productivity in the Bering Sea during the in-situ sampling are described in detail elsewhere (Lomas et al., 2012; Mathis et al., 2010; Moran et al., 2012; Mordy et al., 2012; Stabeno et al., 2012a, 2012b). The shelf could be divided into 6 distinct zones based on hydrographic and biogeochemical characteristics. Across the shelf and the entire water column, a front extended along the $50 \mathrm{~m}$ isobath (inner front) while a second front was identified based on temperature at approximately the $100 \mathrm{~m}$ isobath (central front) on the MN and NP transects (not clear on the SL transect). These fronts divided the shelf into 3 domains Coastal Domain, Middle Domain and the Outer Domain. Along the $70 \mathrm{~m}$ isobath, a broad transitional zone was present at $60{ }^{\circ} \mathrm{N}$ in hydrography (density and bottom water temperatures), nutrients and chlorophyll dividing the eastern shelf into northern shelf $\left(60^{\circ} \mathrm{N}\right.$ and above) and southern shelf (below $60{ }^{\circ} \mathrm{N}$ ). Over the northern shelf the ice melt influenced the SL and MN transects creating a fresh water lens $\sim 20 \mathrm{~m}$ deep seaward from the inner front. The spatial distributions of nutrients and productivity generally coincided with the frontal transition zones (Lomas et al., 2012; Moran et al., 2012; Mordy et al., 2012; Stabeno et al., 2012a, 2012b). Typical of the study region, the coastal domain was low in macronutrients but high in iron and the outer domain was high in macronutrients but low in iron. Production was high just below the pycnocline with intense subsurface chlorophyll fluorescence maxima and subsurface supersaturation of oxygen (Stabeno et al., 2012a, 2012b). The appearance of chlorophyll fluorescence maximum is common in the middle and outer domain (more intense in the northern shelf) of the study region during summer, where wind speeds are not efficient enough in mixing the water column resulting in a two layer system observed during the study period (Stabeno et al., 2012b). The productivity was lowest in the coastal domain in both the northern and southern shelf, and highest in the middle domain of the northern shelf and middleouter domain of the southern shelf (Lomas et al., 2012; Mathis et al., 2010; Moran et al., 2012).

The surface distribution of absorption properties in the study area has been covered in detail in Naik et al. (2010). The distribution of the absorption budget in the surface and middle 1 depth clearly shows the dominance of $\mathrm{a}_{\mathrm{CDOM}}(443)$ (Fig. 2), except at stations located near the Pribilof Islands and St. Matthews Island where $\mathrm{a}_{\mathrm{PHY}}(443)$ was dominant, which is due to the enhanced production near the islands caused by interaction of tides and currents with bathymetry (Kachel et al., 2002; Stabeno et al., 2008). Patterns of apHY(443) were similar to productivity (Lomas et al., 2012; Mathis et al., 2010; Moran et al., 2012) with the highest values near the Pribilof Islands of the southern shelf and along the central front in the middle domain, and the lowest values throughout the coastal domain. The $a_{P H Y}(443)$ was higher in the middle depths relative to surface (ANOVA, $p=0.005$ ) due to the influence of subsurface chlorophyll maximum. Within $\mathrm{a}_{\mathrm{DG}}(\lambda), \mathrm{a}_{\mathrm{CDOM}}(\lambda)$ was more dominant relative to $\mathrm{a}_{\mathrm{NAP}}(\lambda)$. Higher values of $\mathrm{a}_{\mathrm{CDOM}}(443)$ and $\mathrm{a}_{\mathrm{DG}}(443)$ (ANOVA, $\mathrm{p}=$ 0.007 ) were observed in the coastal domain of the northern shelf showing the influence of Kuskokwim river runoff which is carried to the north by prevailing northern currents and constrained to the coast by the inner front. The inverse correlation between salinity and $\mathrm{a}_{\mathrm{CDOM}}(443)(\mathrm{p}<0.001)$ supports the contribution of river runoff to higher CDOM. The northern shelf $\left(60^{\circ} \mathrm{N}\right.$ and above) showed a higher relative contribution from $\mathrm{CDOM}$ as compared to the southern shelf (below $60 \mathrm{~N}$ ) (ANOVA, $\mathrm{p}=0.003$ ). The increase in contribution of $\mathrm{a}_{\mathrm{PHY}}(443)$ to total absorption was apparent going from surface samples to middle 1 depths, but the contribution of $\mathrm{a}_{\mathrm{CDOM}}(443)$ was still dominant at most stations (Fig. 2). 

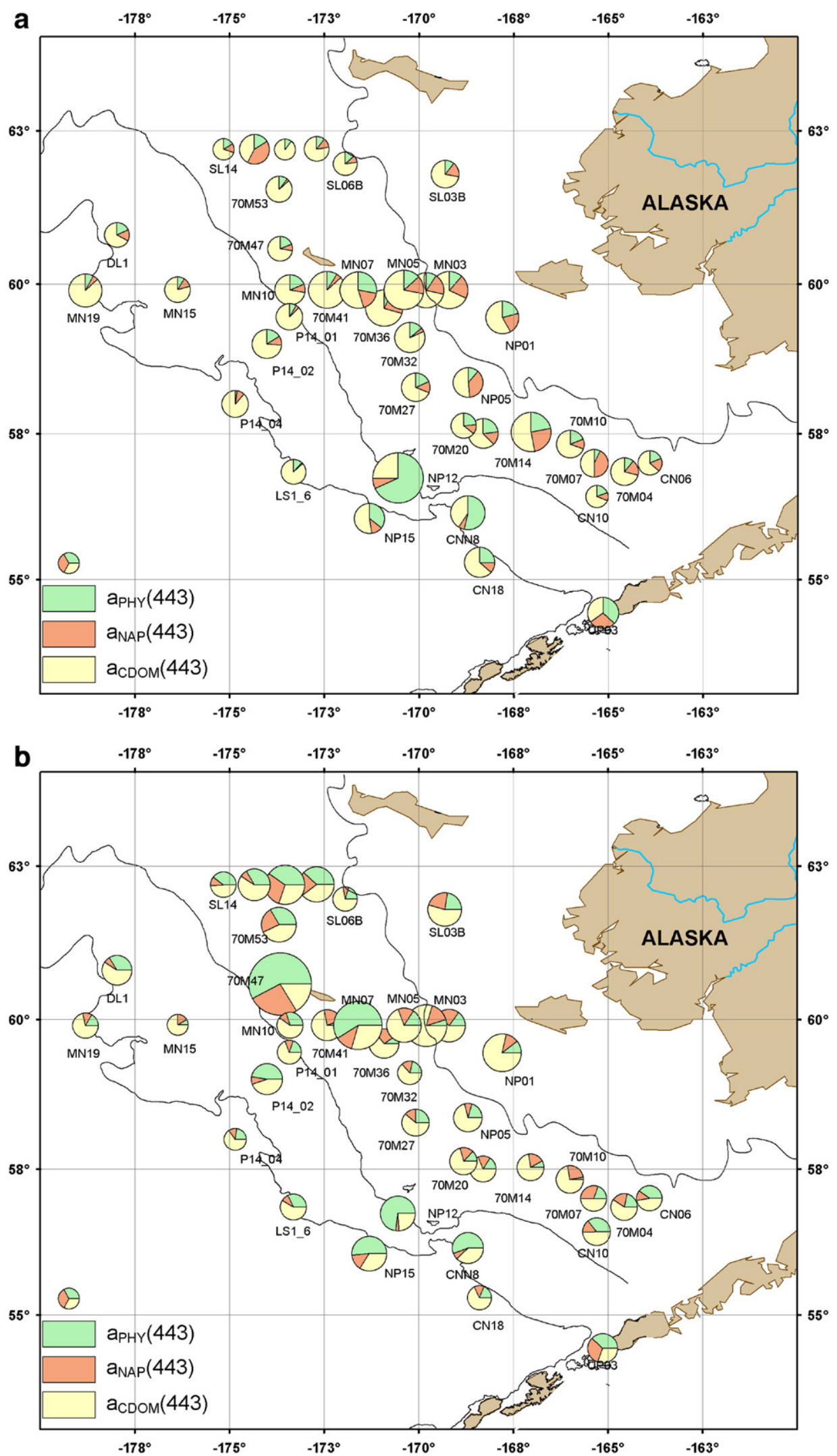

Fig. 2. Spatial distribution of the absorption budget at $443 \mathrm{~nm}$ for (a) surface and (b) middle 1 depths. Green, orange, and yellow represents phytoplankton, NAP, and CDOM percentage contribution, respectively, to total non-water absorption in the pie symbols. The size of pie symbols is proportional to the total non-water absorption at the station locations shown in Fig. 1.

To examine the relative contributions of phytoplankton, NAP and CDOM absorption coefficients to total non-water absorption, the coefficients were displayed on a normalized ternary plot at wavebands that correspond to most ocean color sensors as well as wavebands at which the constituents show characteristic features (Fig. 3). Excluding a few samples (e.g. stations near the Pribilofs), at all depths 

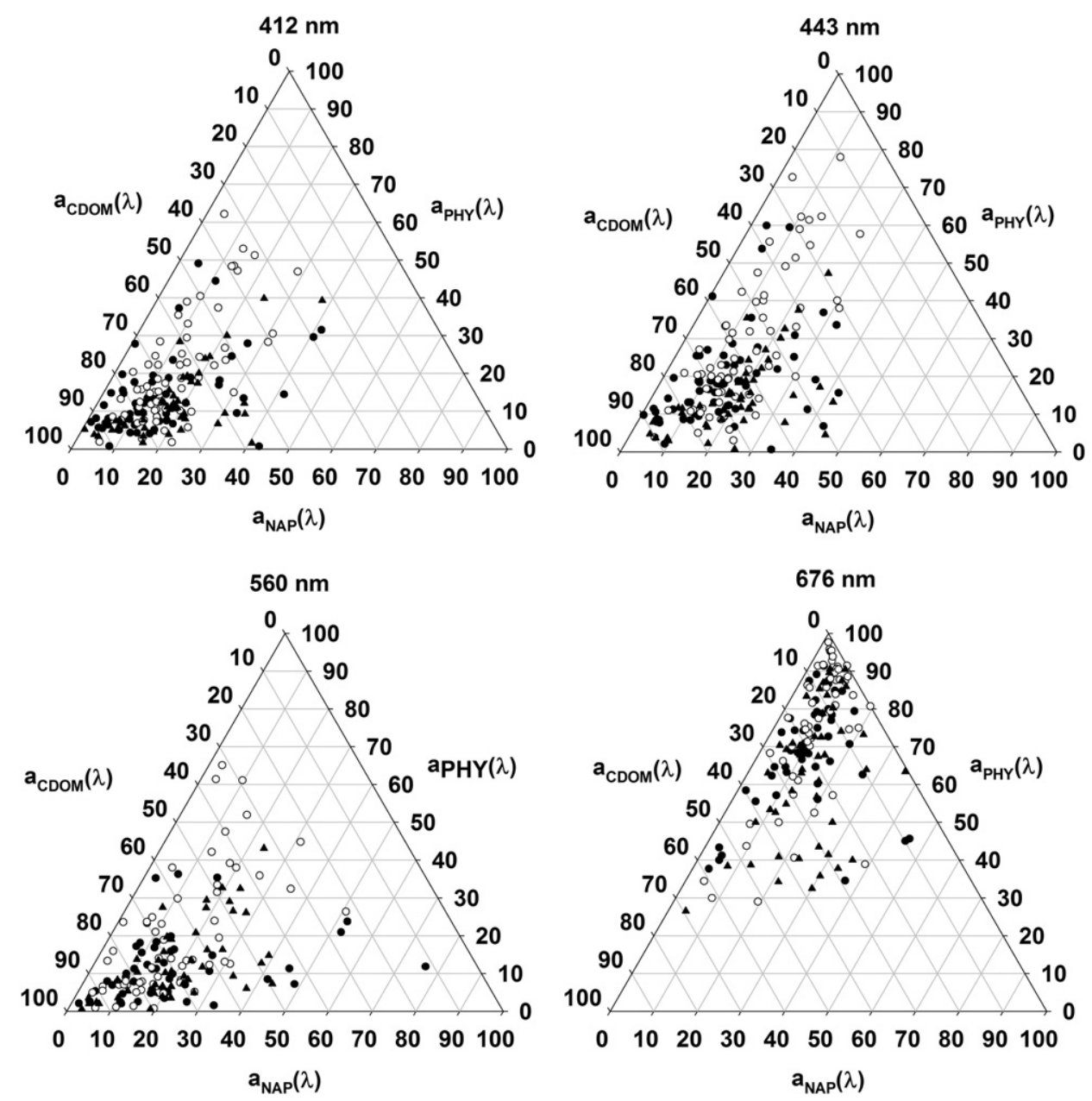

Fig. 3. Absorption budget for the southeastern Bering Sea through ternary plots of phytoplankton absorption $\left(\mathrm{a}_{\mathrm{PHY}}(\lambda)\right)$, NAP absorption $\left(\left(\mathrm{a}_{\mathrm{PHY}}(\lambda)\right)\right)$ and $\mathrm{CDOM}$ absorption $\left(\mathrm{a}_{\mathrm{CDOM}}(\lambda)\right)$ at $412 \mathrm{~nm}, 443 \mathrm{~nm}, 560 \mathrm{~nm}$ and $676 \mathrm{~nm}$ for surface (black filled circles), middle 1 (black open circles), and middle 2 (black filled triangles) depths.

and wavelengths (except $676 \mathrm{~nm}$ ) examined, $\mathrm{a}_{\mathrm{CDOM}}(\lambda)$ dominates the total non-water absorption coefficient followed by $\mathrm{a}_{\mathrm{PHY}}(\lambda)$ and $\mathrm{a}_{\mathrm{NAP}}(\lambda)$. This result is consistent with previous findings (e.g. Belanger et al., 2006; Brown et al., 2008), where a high contribution of $\mathrm{a}_{\mathrm{CDOM}}(\lambda)$ at higher latitudes was observed. At $443 \mathrm{~nm}$, where the chlorophyll-a absorption is maximum, $a_{\mathrm{PHY}}(\lambda) / \mathrm{a}_{\mathrm{T}}-\mathrm{w}(\lambda), \mathrm{a}_{\mathrm{NAP}}(\lambda) / \mathrm{a}_{\mathrm{T}}-\mathrm{w}(\lambda)$, and $\mathrm{a}_{\mathrm{CDOM}}(\lambda) / \mathrm{a}_{\mathrm{T}}-\mathrm{w}(\lambda)$ was $20 \%, 14 \%$, and $66 \%$, respectively for surface samples, $28 \%, 15 \%$, and $57 \%$, respectively for middle1 depth, and $19 \%$, $16 \%$, and $65 \%$, respectively for middle 2 depth. The relative contribution of each component remains similar from the surface to below the chlorophyll-a maximum with the only noticeable change being the increase in $\mathrm{a}_{\mathrm{PHY}}(443) / \mathrm{a}_{\mathrm{T}}-\mathrm{w}(443)$ and corresponding decrease in $\mathrm{a}_{\mathrm{CDOM}}(443) / \mathrm{a}_{\mathrm{T}}-\mathrm{w}(443)$ at middle 1 depths. The CDOM contribution to total non-water absorption was generally dominant in the near ultraviolet region of the spectrum ( $380 \mathrm{~nm}$ - data not shown) and nearly null in the red region $(676 \mathrm{~nm})$. The highest relative contribution of $a_{N A P}(\lambda)$ to $a_{T}-w(\lambda)$ was at $560 \mathrm{~nm}$ and of $a_{P H Y}(\lambda)$ to $a_{T}-w(\lambda)$ was at $676 \mathrm{~nm}$. The relative contribution of $\mathrm{a}_{\mathrm{DG}}(443)$ was around $80 \%$ near the surface, which is slightly higher than the range (70\% at $443 \mathrm{~nm}$ ) of satellite estimates provided by Siegel et al. (2005) for the study region.

\subsection{Relationship of chlorophyll-a with absorption}

The $\mathrm{a}_{\mathrm{PHY}}(443)$ and $\mathrm{a}_{\mathrm{P}}(443)$ ranged two orders of magnitude from 0.002 to $0.370 \mathrm{~m}^{-1}$ and 0.007 to $0.420 \mathrm{~m}^{-1}$ respectively, while $\mathrm{a}_{\mathrm{DG}}(443)$ and $\mathrm{a}_{\mathrm{T}}-\mathrm{w}(443)$ ranged one order of magnitude, 0.032
$0.207 \mathrm{~m}^{-1}$ and $0.057-0.520 \mathrm{~m}^{-1}$ respectively, corresponding with a two orders of magnitude chlorophyll-a range of $0.04-32.30 \mathrm{mg} \mathrm{m}^{-3}$ (Fig. 4). A non-linear relationship expressed as a power function applied between $\mathrm{a}_{\mathrm{PHY}}(\lambda), \mathrm{a}_{\mathrm{P}}(\lambda), \mathrm{a}_{\mathrm{DG}}(\lambda)$, and $\mathrm{a}_{\mathrm{T}}-\mathrm{w}(\lambda)$ at $443 \mathrm{~nm}$ and $676 \mathrm{~nm}$ along with chlorophyll-a showed significant correlation, consistent with other studies (Table 2) (Bricaud et al., 2004; Cota et al., 2003). The relation between $\mathrm{a}_{\mathrm{PHY}}(443)$ and chlorophyll-a obtained for this study was similar to the Matsuoka et al. (2007) study for the Chukchi Sea and the western part of southern Beaufort Sea. For chlorophyll-a concentrations $<10 \mathrm{mg} \mathrm{m}^{-3}$, the $\mathrm{a}_{\mathrm{PHY}}(443)$ values in this study are lower than the values estimated using the middle and lower latitudes relationship of Bricaud et al. (1998) $\left(\mathrm{a}_{\mathrm{PHY}}(443)=0.0378^{*}\right.$ chlorophyll-a ${ }^{0.627}$ ), north polar Atlantic relationship during summer of Stramska et al. (2006) $\left(\mathrm{a}_{\mathrm{PHY}}(443)=0.058^{*}\right.$ chlorophyll-a $\left.{ }^{0.575}\right)$, Labrador Sea relationship of Cota et al. (2003) $\left(a_{\mathrm{PHY}}(443)=0.0402^{*}\right.$ chlorophyll-a $\mathrm{a}^{0.578}$ ) and higher than the values estimated by the western Arctic relationship of Wang et al. (2005) $\left(\mathrm{a}_{\mathrm{PHY}}(443)=0.0151^{*}\right.$ chlorophyll-a $\mathrm{a}^{0.957}$ ). This suggests a need for a cautious approach towards generalization of bio-optical properties of polar and lowerlatitude regions. The $\mathrm{a}_{\mathrm{PHY}}(443) / \mathrm{a}_{\mathrm{P}}(443)$ ratio values ranged between 0.25 and 0.91 , while $\mathrm{a}_{\mathrm{NAP}}(443) / \mathrm{a}_{\mathrm{P}}(443)$ ranged between 0.11 and 0.75 , and are within the ranges reported in literature from different regions (Bricaud et al., 1995, 2004; Cleveland, 1995). Despite this variability, $\mathrm{a}_{\mathrm{PHY}}(443)$ and $\mathrm{a}_{\mathrm{NAP}}(443)$ contributed on an average $62 \%$ and $38 \%$ respectively to $\mathrm{a}_{\mathrm{P}}(443)$, for samples at all stations and depths. The $a_{D G}(443)$ showed only a weak correlation with chlorophyll-a (Table 2, Fig. $4 b)$. Within $a_{D G}(443), a_{N A P}(\lambda)$ showed a significant positive 

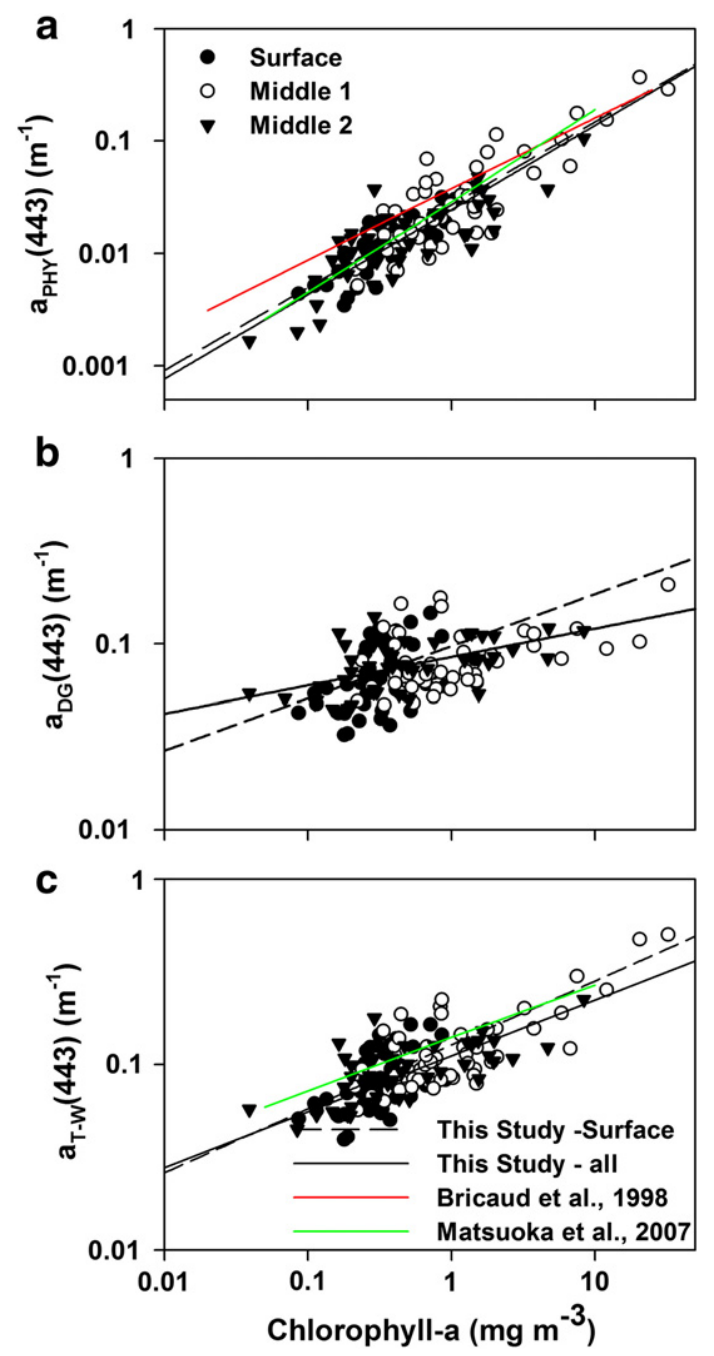

Fig. 4. Relationship between chlorophyll-a and (a) phytoplankton absorption at $443 \mathrm{~nm}$ (a $\left.\mathrm{aPY}_{\mathrm{PH}}(443)\right)$ ), (b) NAP plus CDOM absorption at $443 \mathrm{~nm}$ (a $\mathrm{a}_{\mathrm{DG}}(443)$ ), and (c) total absorption minus water at $443 \mathrm{~nm}\left(\mathrm{a}_{\mathrm{T}}-\mathrm{w}(443)\right)$. Regression fits for surface only (dashed lines) and all depths (solid lines) are shown. The statistics of the fit are shown in Table 2. For comparison, regression fits from literature are also shown Bricaud et al. (1998) (red solid line) and Matsuoka et al. (2007) (green solid line)). See Fig. 3 for symbols.

relation with chlorophyll-a, while $\mathrm{a}_{\mathrm{CDOM}}(\lambda)$ was poorly correlated with chlorophyll-a (Table 2). The weak correlation between $\mathrm{a}_{\mathrm{CDOM}}(443)$ and chlorophyll-a was also seen in other high northern latitudes studies

Table 2

Coefficients and their standard error (in brackets), $\mathrm{r}^{2}$ (coefficient of determination) and number of samples $(\mathrm{n})$ for the power fit expressed as: $a_{X}(\lambda)=A_{X}(\lambda)[\text { chlorophyl }-a]^{\left(B_{X}(\lambda)\right)}$ for all stations and depths; where subscript $\mathrm{x}$ indicates PHY (phytoplankton absorption), $\mathrm{P}$ (particulate absorption), NAP (Non-algal particulate), CDOM (Colored dissolved organic matter), DG (CDOM + NAP) or T - W (total absorption minus water). $\lambda$ is either $443 \mathrm{~nm}$ or $676 \mathrm{~nm}$. * indicates not statistically significant.

\begin{tabular}{lllll}
\hline & \multicolumn{4}{l}{ This study (ANOVA; $<0.001)$} \\
\cline { 2 - 5 } & $\mathrm{A}$ & $\mathrm{B}$ & $\mathrm{r}^{2}$ & $\mathrm{n}$ \\
\hline $\mathrm{a}_{\mathrm{PHY}}(443)$ & $0.026(0.001)$ & $0.758(0.025)$ & 0.88 & 143 \\
$\mathrm{a}_{\mathrm{P}}(443)$ & $0.047(0.001)$ & $0.646(0.020)$ & 0.85 & 143 \\
$\mathrm{a}_{\mathrm{NAP}}(443)$ & $0.020(0.001)$ & $0.427(0.036)$ & 0.58 & 143 \\
$\mathrm{a}_{\mathrm{CDOM}}(443)^{*}$ & $0.050(0.002)$ & $0.070(0.038)$ & 0.12 & 143 \\
$\mathrm{a}_{\mathrm{DG}}(443)$ & $0.085(0.002)$ & $0.152(0.021)$ & 0.30 & 143 \\
$\mathrm{a}_{\mathrm{T}}-\mathrm{w}(443)$ & $0.120(0.002)$ & $0.360(0.017)$ & 0.66 & 143 \\
$\mathrm{a}_{\mathrm{PHY}}(676)$ & $0.010(0.001)$ & $0.934(0.028)$ & 0.87 & 143 \\
$\mathrm{a}_{\mathrm{P}}(676)$ & $0.012(0.001)$ & $0.853(0.034)$ & 0.77 & 143 \\
$\mathrm{a}_{\mathrm{T}}-\mathrm{w}(676)$ & $0.014(0.001)$ & $0.781(0.012)$ & 0.75 & 143 \\
\hline
\end{tabular}

(Matsuoka et al., 2007; Wang et al., 2005), which can be attributed to CDOM processes being out of phase with phytoplankton biomass or production and that most $\mathrm{CDOM}$ in this region is of terrestrial origin. The $\mathrm{a}_{\mathrm{T}}-\mathrm{w}(443)$ correlated well with chlorophyll-a despite the weak correlation between $\mathrm{a}_{\mathrm{DG}}(443)$ and chlorophyll-a (Fig. 4c, Table 2).

The relationships between ratios of $\mathrm{a}_{\mathrm{PHY}}(443), \mathrm{a}_{\mathrm{CDOM}}(443)$ and $\mathrm{a}_{\mathrm{DG}}(443)$ to $\mathrm{a}_{\mathrm{T}}-\mathrm{w}(443)$ and chlorophyll-a show the relative contribution of each of these components to total non-water absorption in relation to phytoplankton biomass (Fig. 5). The $\mathrm{a}_{\mathrm{PHY}}(443) /$ $\mathrm{a}_{\mathrm{T}}-\mathrm{w}(443)$ ratio increased with increasing chlorophyll-a with large variability at chlorophyll-a $<1 \mathrm{mg} \mathrm{m}^{-3}$ (Fig. 5a). The $\mathrm{a}_{\text {сDом }}(443) /$ $\mathrm{a}_{\mathrm{T}}-\mathrm{w}(443)$ ratio decreased with increasing chlorophyll-a, emphasizing that as phytoplankton biomass increases, $\mathrm{a}_{\mathrm{CDOM}}(443)$ becomes less important relative to the $\mathrm{a}_{\mathrm{P}}(443)$ in $\mathrm{a}_{\mathrm{T}}-\mathrm{w}(443)$ (Fig. 5b). The inverse relation between $\mathrm{a}_{\mathrm{DG}}(443) / \mathrm{a}_{\mathrm{T}}-\mathrm{w}(443)$ and chlorophyll-a was not as strong as between $\mathrm{a}_{\mathrm{CDOM}}(443) / \mathrm{a}_{\mathrm{T}}-\mathrm{w}(443)$ ratio and chlorophyll-a and was relatively constant up to chlorophyll-a value of $5 \mathrm{mg} \mathrm{m}^{-3}$ (Fig. 5c). The most prominent outcome of this relation is the strong contribution of $\mathrm{a}_{\mathrm{DG}}(443)$ to the $\mathrm{a}_{\mathrm{T}}-\mathrm{w}(443)$; even at chlorophyll-a concentrations of $7 \mathrm{mg} \mathrm{m}^{-3}, \mathrm{a}_{\mathrm{DG}}(443)$ contributed to more than half
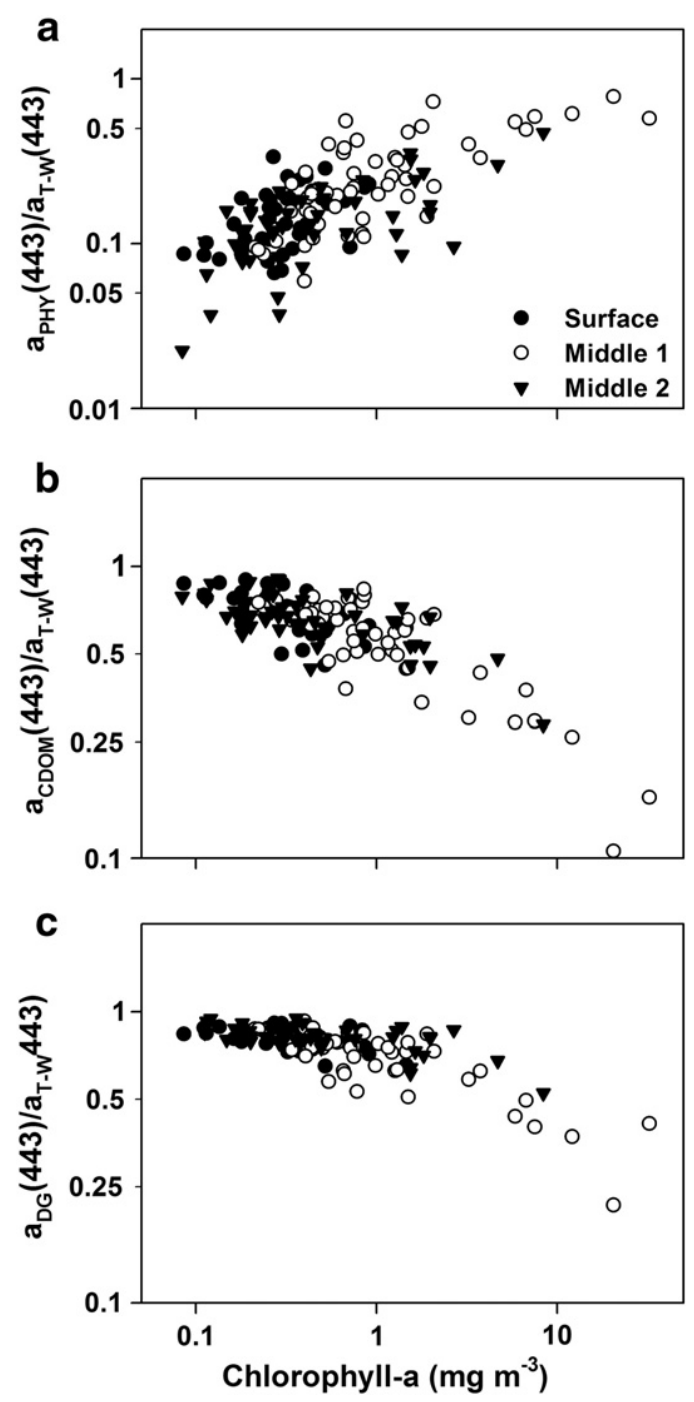

Fig. 5. Relationship between chlorophyll-a and absorption ratios of (a) phytoplankton absorption and total absorption minus water at $443 \mathrm{~nm}\left(\mathrm{a}_{\mathrm{PHY}}(443) / \mathrm{a}_{\mathrm{T}}-\mathrm{w}_{\mathrm{w}}(443)\right)$, (b) CDOM absorption and total absorption minus water at $443 \mathrm{~nm}\left(\mathrm{a}_{\mathrm{CDOM}}(443)\right.$ / $\mathrm{a}_{\mathrm{T}}-\mathrm{w}(443)$ ), and (c) CDOM plus NAP absorption and total absorption minus water at $443 \mathrm{~nm}\left(\mathrm{a}_{\mathrm{DG}}(443) / \mathrm{a}_{\mathrm{T}}-\mathrm{w}(443)\right)$. Note that $\mathrm{y}$-axis is in log scale. See Fig. 3 for symbols. 
of $a_{T}-w(443)$. The significance of this result is evident while evaluating the absorption budget in relation to modeling $\mathrm{R}_{\mathrm{rs}}(\lambda)$ and $\mathrm{K}_{\mathrm{d}}(\lambda)$ (Section 3.5).

\subsection{Specific phytoplankton absorption}

The chlorophyll-a specific phytoplankton absorption $\left(\mathrm{a}^{*}{ }_{\mathrm{PHY}}(\lambda)\right)$ showed large variability in the study region (Fig. 6a), which poses problems when $\mathrm{a}^{*}{ }_{\mathrm{PHY}}$ is considered to be constant in many biooptical models (Bannister, 1974; Morel \& Maritorena, 2001). The variability was greater in the blue with values ranging from 0.003 to $0.120 \mathrm{~m}^{2}(\mathrm{mg} \mathrm{chl}-\mathrm{a})^{-1}$ at $443 \mathrm{~nm}$ than in the red $(676 \mathrm{~nm})$ region of the spectrum where it ranged from 0.002 to $0.030 \mathrm{~m}^{2}$ (mg chl-a) $)^{-1}$. Higher concentrations of phaeopigments in some samples caused the peak of the absorption spectra to be shifted towards shorter wavelengths. A marked shoulder at $\sim 475 \mathrm{~nm}$ was observed in some spectra, which is usually associated with alloxanthin and 19 -hexanoyloxyfucoxanthin pigments present in prymnesiophytes (Cota et al., 2003). The prymnesiophyte Phaeocystis was dominant at many stations during the cruise which explains the presence of this feature in the $\mathrm{a}_{\mathrm{PHY}}(\lambda)$ spectra (Moran et al., 2012). The variability in $\mathrm{a}^{*}{ }_{\mathrm{PHY}}(\lambda)$ was not just restricted to the visible region, the UV (300-400 nm) region too showed large variability with high absorption (Fig. 6a). Peaks around $320 \mathrm{~nm}$ were observed in some of the surface values that diminished in magnitude or were mostly absent in samples from middle depths. Peaks around these wavelengths have been attributed to mycosporine like amino acids (MAAs) (Riegger \& Robinson, 1997). MAAs are a group of UV absorbing compounds that act as sunscreens to reduce UV induced damage (Riegger \& Robinson, 1997). The higher amplitude of peaks in the surface samples relative to middle depths indicate that the concentration of MAAs decreased with depth in the study region. The higher presence of MAAs in the surface phytoplankton populations of the region could be due to change in species composition or indicative of photoacclimation processes (Helbling et al., 1996). Photoacclimation processes may result in high relative levels of photo-protective carotenoids (Laurion et al., 2002); the absorption bands of photoprotective carotenoids are in the 400-530 nm range (Bricaud et al., 1995) which could partially explain the relatively high values of $\mathrm{a}_{\mathrm{PHY}}{ }_{\mathrm{PH}}(443)$ in some surface samples.

A decreasing trend of $\mathrm{a}^{*}{ }_{\mathrm{PHY}}(443)$ from 0.120 to $0.003 \mathrm{~m}^{2}$ ( $\mathrm{mg} \mathrm{chl-a})^{-1}$ was observed with increasing chlorophyll-a concentration from 0.04 to $32.30 \mathrm{mg} \mathrm{m}^{-3}$ (Fig. 6b, $\mathrm{p}<0.001$ ). Similar trends are seen for $\mathrm{a}_{\mathrm{PHY}}^{*}(\lambda)$ with chlorophyll-a concentration over the entire visible spectrum. The $a^{*}{ }_{\text {PHY }}(443)$ was consistently lower for our study as compared to the Bricaud et al. (1995) study (Fig. 6b), indicating the change in pigment composition and/or change in pigment packaging. Pigment packaging refers to phytoplankton pigments being less efficient at absorbing light when they are within cell structures relative to when they are in solution resulting in reduction of the pigment absorption (Kirk, 1994; Morel \& Bricaud, 1981). Pigment packaging can be quantified using the Duysens (1956) and Morel and Bricaud (1981) approach, by calculating $\mathrm{Q}_{\mathrm{a}}{ }^{*}(\lambda)$ which is the ratio of $\mathrm{a}_{\mathrm{PHY}}(\lambda)$ and specific phytoplankton absorption of the same pigmented material in suspension. Theoretically, $Q_{a}{ }^{*}(\lambda)$ varies from 1 (no package effect) to 0 (maximal package effect). With $\mathrm{a}_{\text {PHY_sol }}^{*}(676)$ set equal to 0.0207 $\mathrm{m}^{2} \mathrm{mg}^{-1}$ (Bricaud et al., 1995), $\mathrm{Q}_{\mathrm{a}}{ }^{*}(676)$ was calculated. The $\mathrm{Q}_{\mathrm{a}}{ }^{*}(676)$ values decreased from 1.02 to 0.16 with increasing chlorophyll-a concentration (Fig. 6c). However, a large scatter was observed in $\mathrm{Q}_{a}{ }^{*}$ (676) which can be attributed to uncertainty in the $\beta$ factor (Bricaud \& Stramski, 1990). Pigment packaging has been found to be significant at high latitudes as phytoplankton cells acclimate themselves to the low-light and nutrient-rich environment (Cota et al., 2003) and is dependent on the size of phytoplankton cells, with larger cells showing more packaging relative to smaller cells (Bricaud et al., 1995). The blue to red ratio of $\mathrm{a}^{*}{ }_{\mathrm{PHY}}(\lambda)$ can be used as an indicator of
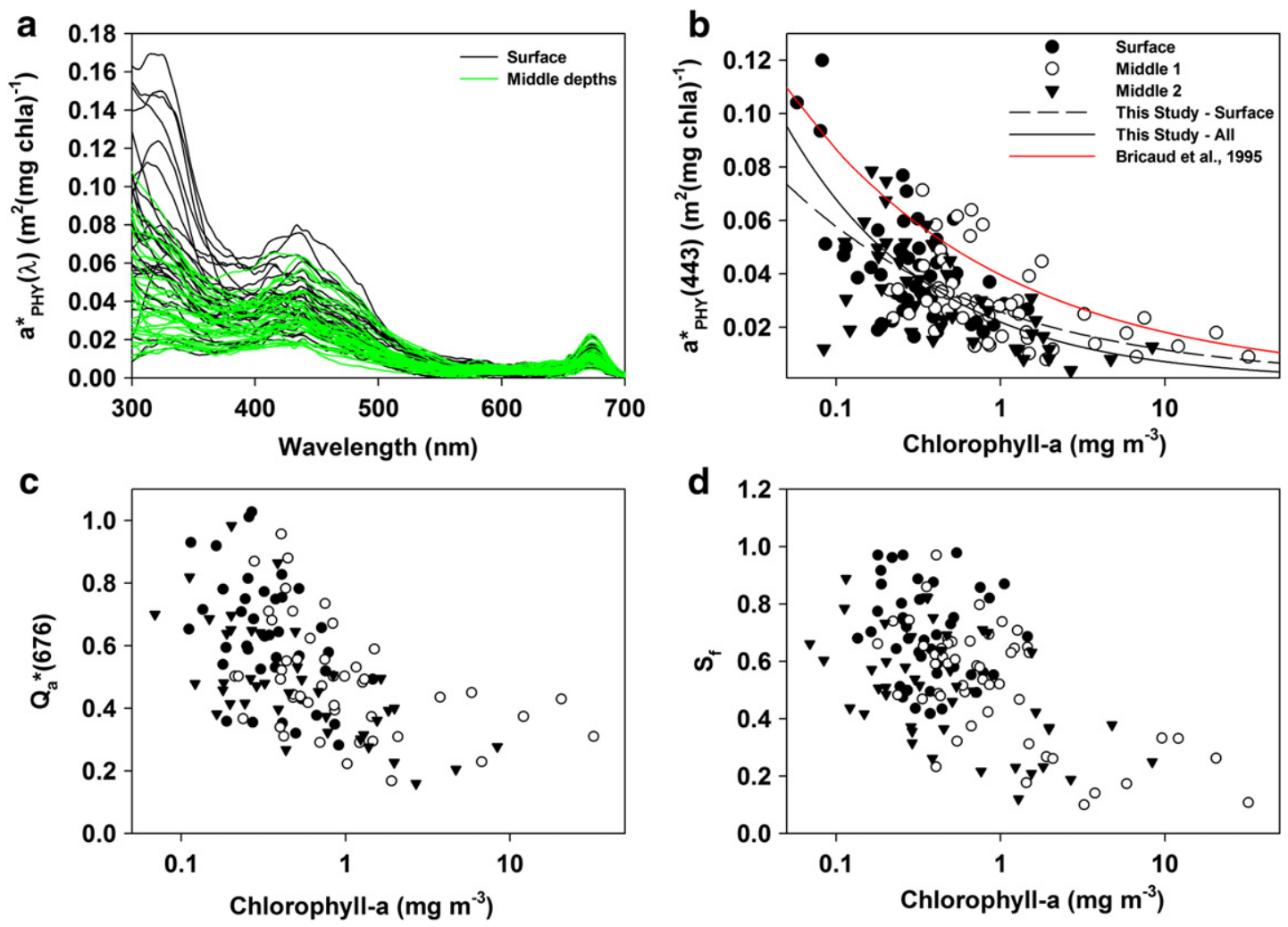

Fig. 6. Specific phytoplankton absorption ( $\mathrm{a}_{\mathrm{pHy}}(\lambda)$ ) (a) variability between 300 and $700 \mathrm{~nm}$ at surface (black solid line) and middle depths (green solid line), and (b) at $443 \mathrm{~nm}$ relation with chlorophyll-a. The regression fit for surface only (dashed black line) and all depths (solid black line) are depicted. For comparison, the regression fit from Bricaud et al. relation with chlorophyll-a. The regression fit for surface only (dashed black line) and all depths (solid black line) are depicted. For comparison, the regression fit from Bricaud et al.
(1995) study (red solid line) is also shown. Relation between chlorophyll-a and (c) quantification of package effect by a dimensionless factor at 676 nm ( $Q^{*}$ a $(676)$ )), (d) spectral size parameter $\left(\mathrm{S}_{\mathrm{f}}\right)$ calculated according to Ciotti et al. (2002). See Fig. 3 for symbols. 
phytoplankton size, with higher values (e.g., $\mathrm{a}_{\mathrm{PHY}}^{*}(443) / \mathrm{a}_{\mathrm{PHY}}^{*}(676)>3$ ) known to be associated with smaller cells (Moore et al., 1995; Stramski \& Morel, 1990). This ratio in our study varied from 6.9 to 1.1 demonstrating approximately a 6-fold decrease as chlorophyll-a increased from 0.04 to $32.3 \mathrm{mg} \mathrm{m}^{-3}$ (data not shown). A large number of $\mathrm{a}_{\mathrm{PHY}}^{*}(443) /$ $\mathrm{a}^{*}{ }_{\mathrm{PHY}}(676)$ values were less than 3 signifying relatively larger size phytoplankton to be dominant and hence larger package effect. However several values of $\mathrm{a}^{*}{ }_{\mathrm{PHY}}(443) / \mathrm{a}_{\mathrm{PHY}}{ }_{\mathrm{P}}(676)$ greater than 3 were also observed.

Another independent method of evaluating the phytoplankton size is by calculating the spectral size parameter $\left(\mathrm{S}_{\mathrm{f}}\right)$ according to the Ciotti et al. (2002) spectral mixing model. The model constrains $S_{\mathrm{f}}$ between 0 and 1 , where $S_{\mathrm{f}}$ values close to 0 indicate phytoplankton community dominated by large cells $(>20 \mu \mathrm{m})$ and $\mathrm{S}_{\mathrm{f}}$ values close to 1 dominated by small cells $(<2 \mu \mathrm{m})$. The computation of $\mathrm{S}_{\mathrm{f}}$ is included in this study as a method independent of chlorophyll-a concentration to support the results obtained from $a^{*}{ }_{\text {PHY }}(443), a^{*}{ }_{\text {PHY }}(443) /$ $a^{*}{ }_{\text {PHY }}(676)$ and $Q_{a}{ }^{*}(676)$. The comparison of measured and reconstructed phytoplankton absorption spectra using computed $\mathrm{S}_{\mathrm{f}}$ was in good agreement with $\mathrm{r}^{2}$ greater than 0.9 averaged over the visible spectrum (400-700 nm) (data not shown). An inverse relationship was seen between $S_{\mathrm{f}}$ and chlorophyll-a (Fig. 6d), with higher values associated with small sized cells and lower chlorophyll-a, and smaller values associated with larger sized cells and higher chlorophyll-a.

The heterogeneity observed in $\mathrm{a}^{*}{ }_{\mathrm{PHY}}(\lambda), \mathrm{S}_{\mathrm{f}}, \mathrm{a}_{\mathrm{PHY}}{ }_{\mathrm{PH}}(443) / \mathrm{a}_{\mathrm{PHY}}{ }_{\mathrm{PH}}(676)$ and $\mathrm{Q}_{\mathrm{a}}{ }^{*}(676)$ is supported by the chlorophyll-a fractionated and cell abundance data from the region (Lomas et al., 2012; Moran et al., 2012). Size fractionated data revealed that about $70 \%$ of chlorophyll-a in middle depths and $47 \%$ of chlorophyll-a in surface samples was attributable to the $>5 \mu \mathrm{m}$ sized phytoplankton cells, however averaged over the entire study area $30 \%$ of vertically integrated chlorophyll-a was from $>5 \mu \mathrm{m}$ (personal communication, Dr. Michael Lomas; Lomas et al., 2012). The phytoplankton cell abundance observations showed that microflagellates (mainly Phaeocystis sp.) followed by diatoms dominated the study region during the sampling period (Moran et al., 2012). The Phaeocystis sp. although small in size (3-5 $\mu \mathrm{m})$ demonstrate significant pigment packaging as they acclimatize to lower light levels (Moisan \& Mitchell, 1999). Although distribution of phytoplankton size classes showed relatively small cells at most stations, stations where large cells dominated were also present (Moran et al., 2012).

Lower $\mathrm{a}_{\mathrm{PHY}}{ }_{\mathrm{PH}}(\lambda)$ values are not uncharacteristic of polar regions (Mitchell \& Holm-Hansen, 1991; Sosik et al., 1992) and have been identified as the cause of the underestimation of chlorophyll-a concentration by ocean color algorithms in the southeastern Bering Sea (Müller-Karger et al., 1990). However, Schallenberg et al. (2008) show that satellite-derived chlorophyll-a in the Bering Sea is often overestimated owing to the influence of higher $\mathrm{a}_{\mathrm{CDOM}}(\lambda)$ although no measurements of absorption coefficients were conducted in the study. In Section 3.5, we discuss the effect of these two co-existing factors (lower $\mathrm{a}_{\text {PHY }}(443)$ and higher $\mathrm{a}_{\mathrm{CDOM}}(\lambda)$ ) on $\mathrm{R}_{\mathrm{rS}}(\lambda)$ and their ratios (hence pigment estimates) in the study region.

\subsection{Parameterization of $a_{P H Y}, a_{D G}$ and $a_{T-W}$}

Ocean color sensors have a limited number of channels that are not sufficient to decipher spectral shape of absorption coefficients over the visible domain. However, parameterization of absorption coefficients developed by using spectral slopes, absorption coefficients at a certain wavelength and/or chlorophyll-a, provides a means of extending absorption measurements at a specific wavelength to absorption for hyperspectral wavelengths (Barnard et al., 1998; Wang et al., 2005). We discuss here the parameterization of $\mathrm{a}_{\mathrm{PHY}}$, $\mathrm{a}_{\mathrm{DG}}$ and $\mathrm{a}_{\mathrm{T}}-\mathrm{w}$ using simple regression models.

\subsubsection{Phytoplankton absorption parameterization through chlorophyll-a and $a_{P H Y}(443)$}

Good correlation between $\mathrm{a}_{\mathrm{PHY}}(443)$ and chlorophyll-a (Fig. 4a), suggests that it would be appropriate to parameterize $\mathrm{a}_{\mathrm{PHY}}(\lambda)$ with chlorophyll-a. Despite the variability seen in the $\mathrm{a}_{\mathrm{PHY}}(\lambda)$ spectra, good correlations were observed between $\mathrm{a}_{\mathrm{PHY}}(\lambda)$ and chlorophyll-a over the visible spectrum using Eq. (7), with weakest correlations in the $450 \mathrm{~nm}$ to $500 \mathrm{~nm}$ range (Table 3). The 450 to $500 \mathrm{~nm}$ is the range where accessory pigments have a significant effect on the $\mathrm{a}_{\mathrm{PHY}}(\lambda)$ spectra, thus the lowest $\mathrm{r}^{2}$. Using this parameterization, the $a^{*}{ }_{\text {PHY }}(\lambda)$ spectra can be modeled for various concentrations of chlorophyll-a. Fig. 7a shows the results of modeling $a^{*}{ }_{\text {PHY }}(\lambda)$ and the apparent flattening of the spectra due to the package effect which was more pronounced with increasing chlorophyll-a. We clearly see that $\mathrm{a}^{*}{ }_{\mathrm{PHY}}(\lambda)$ is lower than the Bricaud et al. (1995) study for all wavelengths in the visible domain.

The $\mathrm{a}_{\mathrm{PHY}}(\lambda)$ can also be parameterized using $\mathrm{a}_{\mathrm{PHY}}(443)$; the regression coefficients and $r^{2}$ for relationship between $\operatorname{apHY}_{\mathrm{PH}}(\lambda)$ and $\mathrm{a}_{\mathrm{PHY}}(443)$ expressed as Eq. (8) are shown in Fig. 7b and Table 3. To test the strength of this parameterization we divided the data randomly into two halves, for one half we developed the parameterization and tested it with the other half. The results of this analysis at specific wavelengths shows a good linear relationship between the measured and modeled $\mathrm{a}_{\mathrm{PHY}}(\lambda)$ (Table 4$)$. Thus, the approach used here is helpful for describing $\mathrm{a}_{\mathrm{PHY}}(\lambda)$ spectra over the visible domain using $\mathrm{a}_{\mathrm{PHY}}(443)$ derived from ocean color.

\subsection{2. $a_{D G}(\lambda)$ parameterization through $a_{D G}(443)$ and $S_{D G}(443)$}

The mean value of the spectral slope of CDOM and NAP $\left(S_{D G}\right)$ was used to parameterize the $a_{D G}(\lambda)$ spectra using Eq. (10). In most ocean color applications CDOM and NAP absorption are considered together, due to their similar spectral shapes. For all samples, the $a_{\text {NAP }}(\lambda)$ and $\mathrm{a}_{\mathrm{CDOM}}(\lambda)$ could be expressed by exponential functions given by Eqs. (6) and (10), respectively. The standard error of both $\mathrm{S}_{\mathrm{CDOM}}$ and $\mathrm{S}_{\mathrm{NAP}}$ estimate was less than $0.1 \%$ and $\mathrm{r}^{2}$ was greater than 0.95 .

Table 3

Coefficients, $\mathrm{r}^{2}$ and 'number of samples (n) at specific wavelengths for the non-linear regression expressed as: $a_{Q}(\lambda)=\alpha_{X}(\lambda)[X]^{\left(\beta_{X}(\lambda)\right)}($ see Eqs. $(7)$ and $(8))$; where $\mathrm{a}_{0}(\lambda)$ is either phytoplankton absorption (2nd and 3rd column from left) or T - W (total absorption minus water) (4th column from left) from $400-700 \mathrm{~nm}$ at $2 \mathrm{~nm}$ interval, $\mathrm{X}$ is chlorophyll-a (2nd column from left), or PHY(phytoplankton absorption) at $443 \mathrm{~nm}$ (3rd column from left), or T - W (total absorption minus water) at $443 \mathrm{~nm}$ (4th column from left), $\lambda$ is the wavelength.

\begin{tabular}{|c|c|c|c|c|c|c|c|c|c|}
\hline \multirow[t]{2}{*}{$\lambda(\mathrm{nm})$} & \multicolumn{3}{|c|}{ Chlorophyll-a n = 143} & \multicolumn{3}{|c|}{$\operatorname{aPHY}_{\mathrm{P}}(443) \mathrm{n}=182$} & \multicolumn{3}{|c|}{$\mathrm{a}_{\mathrm{T}}-\mathrm{w}(443) \mathrm{n}=182$} \\
\hline & $\alpha_{\mathrm{CHL}}(\lambda)$ & $\beta_{\mathrm{CHL}}(\lambda)$ & $r^{2}$ & $\alpha_{\mathrm{PHY}}(\lambda)$ & $\beta_{\mathrm{PHY}}(\lambda)$ & $r^{2}$ & $\alpha_{T-w}(\lambda)$ & $\beta_{\mathrm{T}-w}(\lambda)$ & $r^{2}$ \\
\hline 400 & 0.023 & 0.780 & 0.871 & 0.920 & 1.013 & 0.954 & 0.927 & 0.762 & 0.940 \\
\hline 412 & 0.025 & 0.764 & 0.869 & 0.971 & 0.994 & 0.979 & 0.958 & 0.827 & 0.972 \\
\hline 443 & 0.026 & 0.758 & 0.882 & - & - & - & - & - & - \\
\hline 490 & 0.014 & 0.725 & 0.835 & 0.498 & 0.953 & 0.978 & 0.537 & 1.004 & 0.978 \\
\hline 510 & 0.010 & 0.784 & 0.845 & 0.406 & 1.002 & 0.958 & 0.430 & 1.034 & 0.962 \\
\hline 560 & 0.004 & 0.876 & 0.855 & 0.221 & 1.119 & 0.853 & 0.218 & 1.033 & 0.916 \\
\hline 665 & 0.009 & 0.927 & 0.877 & 0.664 & 1.208 & 0.915 & 0.730 & 1.764 & 0.956 \\
\hline 676 & 0.009 & 0.912 & 0.870 & 0.642 & 1.182 & 0.915 & 0.681 & 1.742 & 0.957 \\
\hline
\end{tabular}



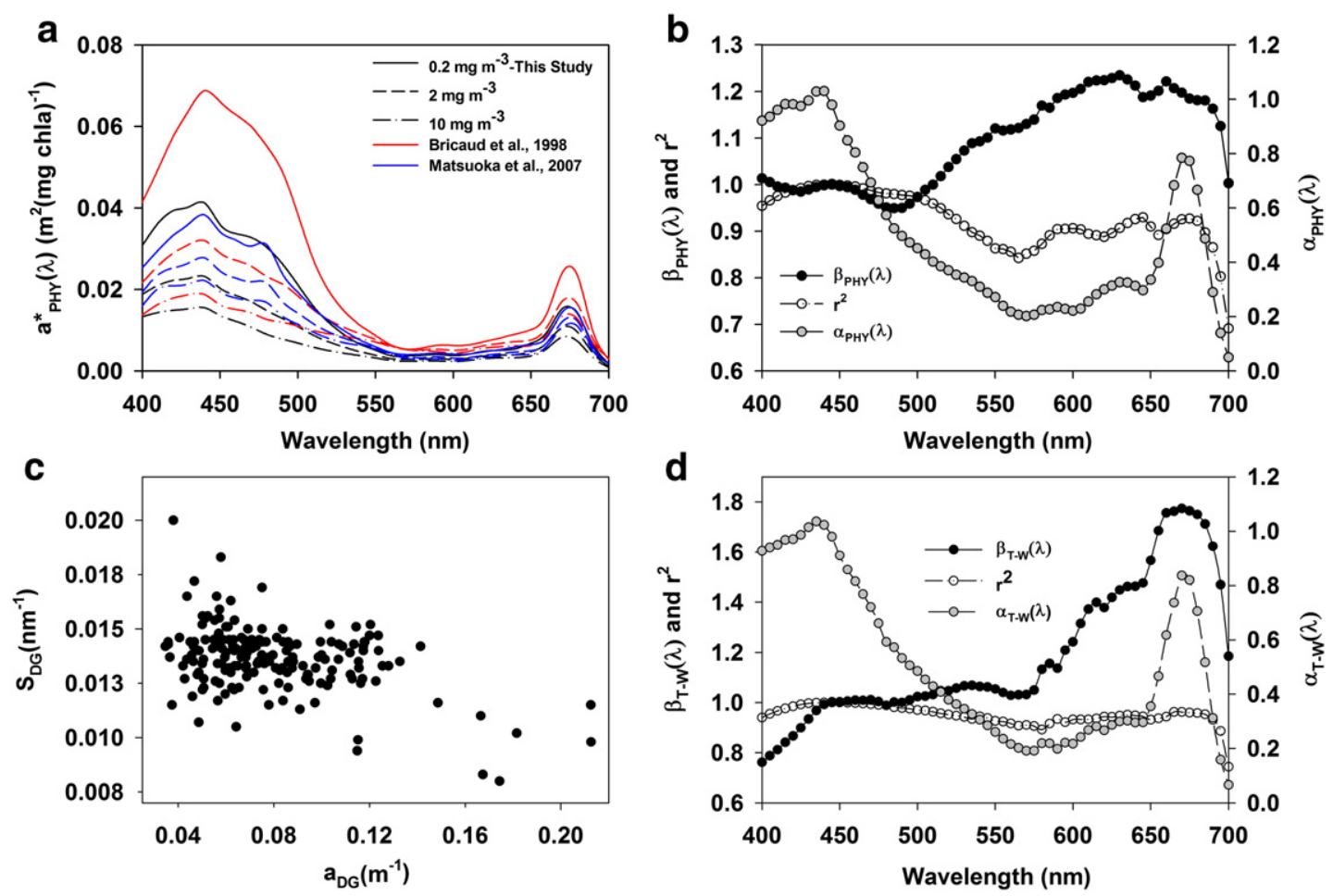

Fig. 7. (a) Modeled specific phytoplankton absorption ( $a^{*}{ }_{\text {PHY }}(\lambda)$ ) using Eq. (7) showing the flattening effect of absorption spectra with increasing chlorophyll-a. For comparison, spectra from Bricaud et al. (1995) and Matsuoka et al. (2007) are also shown. (b) Coefficients and $\mathrm{r}^{2}$ of Eq. (8) for parameterization of apHY(443), (c) relation between spectra slope parameter and CDOM plus NAP absorption at $443 \mathrm{~nm}\left(\mathrm{a}_{\mathrm{DG}}(443)\right.$, and (d) coefficients and $\mathrm{r}^{2}$ of Eq. (8) for parameterization of $\mathrm{a}_{\mathrm{T}}-\mathrm{w}(\lambda)$ ).

The $\mathrm{S}_{\mathrm{NAP}}$ values were found to vary between 0.007 and $0.016 \mathrm{~nm}^{-1}$ with an average value of $0.0110 \pm 0.0017 \mathrm{~nm}^{-1}$, while the $\mathrm{S}_{\mathrm{CDOM}}$ values were found to vary between 0.008 and $0.022 \mathrm{~nm}^{-1}$ with an average value of $0.0151 \pm 0.0016 \mathrm{~nm}^{-1}$. The $\mathrm{S}_{\mathrm{CDOM}}$ showed a weak inverse relation with $\mathrm{a}_{\mathrm{CDOM}}(443)\left(\mathrm{r}^{2}=0.29, \mathrm{p}<0.001\right)$ whereas $\mathrm{S}_{\mathrm{NAP}}$ did not show any significant trend with $\mathrm{a}_{\mathrm{NAP}}(443)$. The $\mathrm{S}_{\mathrm{NAP}}$ values were less variable as compared to $\mathrm{S}_{\mathrm{CDOM}}$ consistent with several studies (Babin et al., 2003). The $S_{D G}$ values varied between 0.009 and $0.020 \mathrm{~nm}^{-1}$ and did not show any clear inverse relationship with $a_{D G}(443)\left(r^{2}=0.2\right)$ (Fig. 7c). The utility of the parameterization of $a_{D G}(\lambda)$ with $S_{D G}$ was tested by calculating the mean value of $S_{D G}$ for one half of the data and applying this mean value of $S_{D G}$ to the remaining half. The linear regression results between the modeled and measured $\mathrm{a}_{\mathrm{DG}}(\lambda)$ are shown in Table 4 ; the $\mathrm{r}^{2}$ was greater than 0.9 and slope close to 1 for the wavelengths analyzed.

The procedure for parameterization of $\mathrm{a}_{\mathrm{T}}-\mathrm{w}(\lambda)$ was similar to the parameterization of $\mathrm{a}_{\mathrm{PHY}}(\lambda)$. The coefficients and $\mathrm{r}^{2}$ of the regression expressed by Eq. (8) are shown in Fig. $7 d$ and Table 3. The parameter $\alpha_{T}-w(\lambda)$ has a spectral shape similar in appearance to $\mathrm{a}_{\mathrm{PHY}}(\lambda)$ which is interesting as the $\mathrm{a}_{\mathrm{T}}-\mathrm{w}(\lambda)$ also includes absorption

\section{Table 4}

Linear regression (no intercept) results at specific wavelengths between modeled (see Eqs. (7), (8), and (10)) and measured values of phytoplankton absorption $\left(\mathrm{a}_{\mathrm{PHY}}(\lambda)\right.$ ), colored dissolved organic matter (CDOM) plus non-algal matter (NAP) absorption $\left(\mathrm{a}_{\mathrm{DG}}(\lambda)\right)$ and total absorption minus water $\left(\mathrm{a}_{\mathrm{T}}-\mathrm{w}(\lambda)\right)$. $\lambda$ is the wavelength.

\begin{tabular}{|c|c|c|c|c|c|c|c|c|c|}
\hline \multirow{2}{*}{$\frac{\mathrm{n}=91}{\lambda(\mathrm{nm})}$} & \multicolumn{3}{|c|}{$\mathrm{a}_{\mathrm{PHY}}(\lambda)$} & \multicolumn{3}{|c|}{$\mathrm{a}_{\mathrm{DG}}(\lambda)$} & \multicolumn{3}{|c|}{$\mathrm{a}_{\mathrm{T}}-\mathrm{w}(\lambda)$} \\
\hline & Slope & $r^{2}$ & $\overline{\text { rmse }}$ & Slope & $\mathrm{r}^{2}$ & $\overline{\text { rmse }}$ & Slope & $r^{2}$ & rmse \\
\hline 400 & 0.987 & 0.984 & 0.005 & 1.026 & 0.997 & 0.002 & 0.996 & 0.947 & 0.004 \\
\hline 412 & 0.998 & 0.992 & 0.004 & 0.993 & 0.997 & 0.002 & 0.997 & 0.979 & 0.003 \\
\hline 490 & 1.051 & 0.987 & 0.004 & 0.986 & 0.993 & 0.003 & 0.988 & 0.963 & 0.002 \\
\hline 510 & 1.064 & 0.980 & 0.003 & 0.974 & 0.959 & 0.005 & 0.964 & 0.924 & 0.004 \\
\hline 560 & 0.996 & 0.956 & 0.005 & 0.929 & 0.908 & 0.007 & 0.900 & 0.910 & 0.005 \\
\hline 665 & 1.047 & 0.963 & 0.006 & - & - & - & 0.901 & 0.920 & 0.007 \\
\hline 676 & 1.050 & 0.959 & 0.007 & - & - & - & 0.930 & 0.905 & 0.007 \\
\hline
\end{tabular}

from CDOM and detrital matter. This also indicated that although $\mathrm{a}_{\mathrm{DG}}(\lambda)$ has a larger contribution to $\mathrm{a}_{\mathrm{T}}-\mathrm{w}(\lambda)$ compared to $\mathrm{a}_{\mathrm{PHY}}(\lambda)$, the variation in $\mathrm{a}_{\mathrm{PHY}}(\lambda)$ was much larger compared to $\mathrm{a}_{\mathrm{DG}}(\lambda)$. $A$ good linear relationship was seen between the measured and modeled $\mathrm{a}_{\mathrm{T}}-\mathrm{w}(\lambda)$ with slope close to 1 and $\mathrm{r}^{2}$ greater than 0.9 (Table 4 ). The results obtained here are of significance to satellite remote sensing since bio-optical information is limited in many cases.

3.5. Influence of absorption on remote sensing reflectance $\left(R_{r s}(\lambda)\right)$ and diffuse attenuation coefficient of downwelling irradiance $\left(K_{d}(\lambda)\right)$

The primary purpose of this section is to describe the effect of absorption on the above water and underwater light field, while the blue to green reflectance ratios and chlorophyll estimates are described for completeness. Higher than normal CDOM concentrations are known to clearly produce an overestimate of chlorophyll, since they absorb strongly at $443 \mathrm{~nm}$ and less so at $550 \mathrm{~nm}$ and $560 \mathrm{~nm}$. Brown et al. (2008) showed that the second order variability of chlorophyll-a concentration could be explained by CDOM and particulate backscattering. So, at high latitudes CDOM and backscattering may be erroneously contributing to chlorophyll-a estimates from ocean color sensors.

To investigate the effect of absorption on $\mathrm{R}_{\mathrm{rs}}(\lambda)$ and $\mathrm{K}_{\mathrm{d}}(\lambda)$, they were modeled using IOPs (absorption and backscattering). The IOPs that were used in modeling were from both discrete measurements as well as continuous vertical profile measurements. A comparison was made between modeled and radiometer measured $R_{\mathrm{rs}}(\lambda)$ and $\mathrm{K}_{\mathrm{d}}(\lambda)$. To evaluate the influence of CDOM absorption, $\mathrm{R}_{\mathrm{rs}}(\lambda)$ and $\mathrm{K}_{\mathrm{d}}(\lambda)$ were modeled using total absorption as well as total absorption minus the absorption from CDOM (see Methods, Section 2.4). Optical closure between $\mathrm{R}_{\mathrm{rs}}(\lambda)$ (and $\mathrm{K}_{\mathrm{d}}(\lambda)$ ) and IOPs (both discrete as well as continuous) was reasonable at all wavelengths between $400 \mathrm{~nm}$ to $700 \mathrm{~nm}$ at $1 \mathrm{~nm}$ interval, providing confidence to the accuracy of individual measurements (Fig. 8). The average percent difference (a.p.d.) between discrete and continuous IOPs based model was less 
MN5

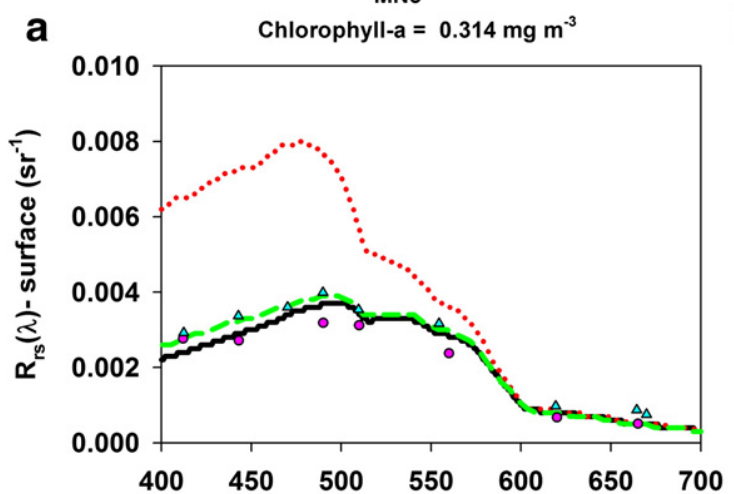

b

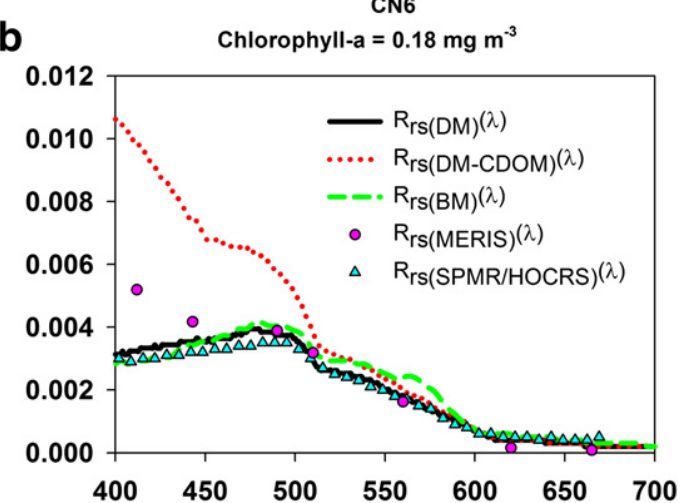

c

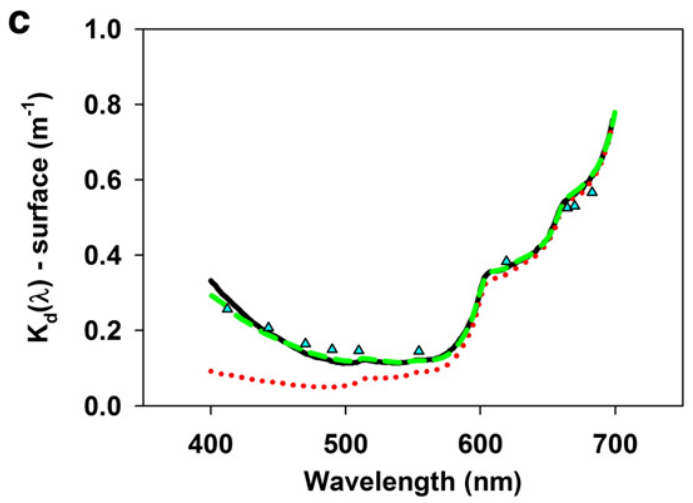

d

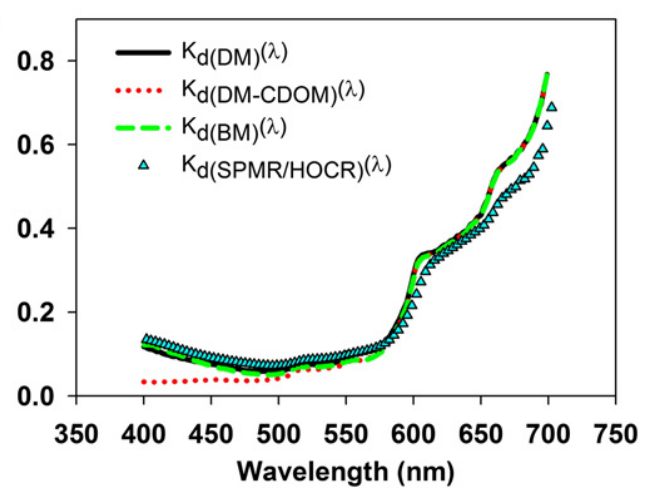

Fig. 8. Representative spectra of remote sensing reflectance $\left(\mathrm{R}_{\mathrm{rs}}(\lambda)\right)(\mathrm{a}, \mathrm{b})$ and diffuse attenuation coefficient of downwelling irradiance $\left(\mathrm{K}_{\mathrm{d}}(\lambda)\right)$ (c,d), modeled at hyperspectral wavelengths from IOPs (absorption and scattering (model - see Eqs. (13), (14) or in-situ)) for discrete measurement (solid black line), discrete measurements minus the contribution from CDOM (dotted red line), and continuous measurements using a bio-optical package (BOP) (dashed green line). Also shown for comparison are the $\mathrm{R}_{\mathrm{rs}}(\lambda)$ and $\mathrm{K}_{\mathrm{d}}(\lambda)$ spectra determined from in-water radiometric measurements using either an SPMR or HyperOCR and MERIS derived $R_{\mathrm{rS}}(\lambda)$.

than $23 \%(\mathrm{n}=25)$ for $\mathrm{R}_{\mathrm{rs}}(\lambda)$ and $\mathrm{K}_{\mathrm{d}}(\lambda)$ at all wavelengths, with the largest differences in the red wavelengths. For the IOP modeled and radiometer measured $R_{r s}(\lambda)$ and $K_{d}(\lambda)$, the a.p.d. was 25\% $(n=23)$ (except at red wavelengths a.p.d. was less than $37 \%$ ) and $19 \%(n=23)$ (except at red wavelengths a.p.d. was less than 20\%), respectively. The modeled and measured $R_{\mathrm{rs}}(\lambda)$ showed fairly good agreement with MERIS retrieved $R_{\mathrm{rS}}(\lambda)$, with a.p.d. less than $30 \%(n=12)$ except at red wavelengths (a.p.d. less than 39\%). The results from the closure between $\mathrm{R}_{\mathrm{rs}}(\lambda)$ and IOPs is significant for empirical formulations linking $\mathrm{R}_{\mathrm{rs}}(\lambda)$ to IOPs and for accurate modeling of $\mathrm{R}_{\mathrm{rS}}(\lambda)$ or IOPs.

The effect of $\mathrm{a}_{\mathrm{CDOM}}(\lambda)$ on the blue wavelengths and to a lesser extent on the green wavelengths was apparent on the $R_{r s}(\lambda)$ spectra for most of the samples analyzed (Fig. 8a, b). Based on the optical closure analysis we found that for a chlorophyll-a range of 0.05 to $0.8 \mathrm{mg} \mathrm{m}^{-3}$ the blue to green $\mathrm{R}_{\mathrm{rs}}(\lambda)$ were lower causing chlorophyll-a to be overestimated, while for chlorophyll-a greater than $1 \mathrm{mg} \mathrm{m}^{-3}$ the blue to green $\mathrm{R}_{\mathrm{rs}}(\lambda)$ ratios were higher causing chlorophyll-a to be underestimated using the OC4.v6 algorithm, a fourth-order polynomial of the maximum band ratio of four bands (O'Reilly et al., 1998) (Fig. 9). We have included Bering Sea data from SeaBASS (Werdell et al., 2003) to supplement our dataset. The lower blue to green $\mathrm{R}_{\mathrm{rs}}(\lambda)$ ratios can be ascribed to the high $\mathrm{a}_{\mathrm{CDOM}}(\lambda)$ and the high backscattering $(>0.002$ at $443 \mathrm{~nm} ; \mathrm{n}=20)$. The $\mathrm{R}_{\mathrm{rs}(\mathrm{DM})}(\lambda)$ in which the backscattering was modeled using a global relationship (Morel \& Maritorena, 2001) and $\mathrm{R}_{\mathrm{rS}(\mathrm{BM})}(\lambda)$ in which backscattering was from in-situ measurements showed good agreement. From differences between $\operatorname{R}_{\mathrm{rs}(\mathrm{DM})}(\lambda)$ and $\mathrm{R}_{\mathrm{rs}(\mathrm{DM}-\mathrm{CDOM})}(\lambda)$, we consider that backscattering had a relatively lesser influence on $R_{\mathrm{rs}}(\lambda)$ as compared to $\mathrm{a}_{\mathrm{CDOM}}(\lambda)$. From comparisons between $\mathrm{R}_{\mathrm{rs}(\mathrm{DM})}(\lambda)$ and $\mathrm{R}_{\mathrm{rs}(\mathrm{DM}-\mathrm{CDOM})}(\lambda)$, we found that the blue to green $\mathrm{R}_{\mathrm{rs}}(\lambda)$ ratios decreased by a factor of $\sim 2$ due to the influence of $\mathrm{a}_{\mathrm{CDOM}}(\lambda)$. At lower chlorophyll-a concentrations, $\mathrm{a}_{\mathrm{CDOM}}(\lambda)$ dominates the light absorption relative to $\mathrm{a}_{\mathrm{PHY}}(\lambda)$ (Fig. $\left.5 b\right)$, hence higher CDOM overrides the lower $\mathrm{a}_{\mathrm{PHY}}^{*}(\lambda)$ causing lower green to blue reflectance ratios resulting in overestimation of chlorophyll-a by OC4.v6 (Fig. 9b). As the chlorophyll-a concentration increases, the contribution of $\mathrm{a}_{\mathrm{PHY}}(\lambda)$ increases (Fig. 5a); here the lower $\mathrm{a}_{\mathrm{PHY}}^{*}(\lambda)$ begins to influence the green to blue reflectance ratios resulting in underestimation of chlorophyll-a by OC4.v6 (Fig. 9b). Comparisons between the algorithm developed especially for the Arctic Ocean (Arctic OC4L, (Cota et al., 2004)) and OC4.v6 revealed similar trends. A chlorophyll algorithm for the study region (BS_OC4) was developed using in-situ radiometer derived $R_{r s}(\lambda)$ ratios and chlorophyll-a (Fig. 9b):

$\operatorname{CHL}(B S)=10^{\wedge}\left(0.457-3.609^{*} R\right)$

Where $\mathrm{R}=\log \operatorname{Rrs}(443>490>510 / 555)$. There was no significant difference between the chlorophyll algorithm developed in this study (BS_OC4) and Arctic OC4L (Fig. 9b, ANOVA: p > 0.5). The corresponding 3-band MODIS chlorophyll algorithm is given by:

$\operatorname{Chl}($ BS_OC3M $)=10^{\wedge}\left(0.437-3.537^{*} \mathrm{R}\right)$

where $\mathrm{R}=\log \operatorname{Rrs}(443>490 / 555)$; $\mathrm{r} 2=0.85, \mathrm{n}=45$. To comprehend the seasonal variation of CDOM and seasonal succession of phytoplankton on the trends seen between OC4.v6 and BS_OC4, we analyzed these two algorithms for the months from May-October, 2008 using monthly MODIS SMI images (http://oceancolor.gsfc.nasa. gov/cgi/l3). The $\operatorname{Rrs}(490)$ and $\operatorname{Rrs}(510)$ values used in Eq. (17) were obtained using a cubic spline interpolation from the MODIS data. Pixels ( $n=178$ for each month) for which data was present for all of the 6 months within the polygon enclosing the study area were chosen for this analysis. The largest difference was seen in the months 


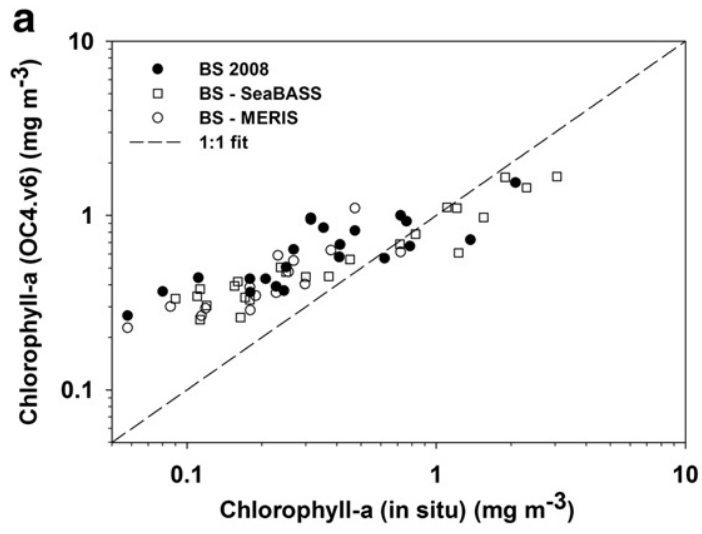

b
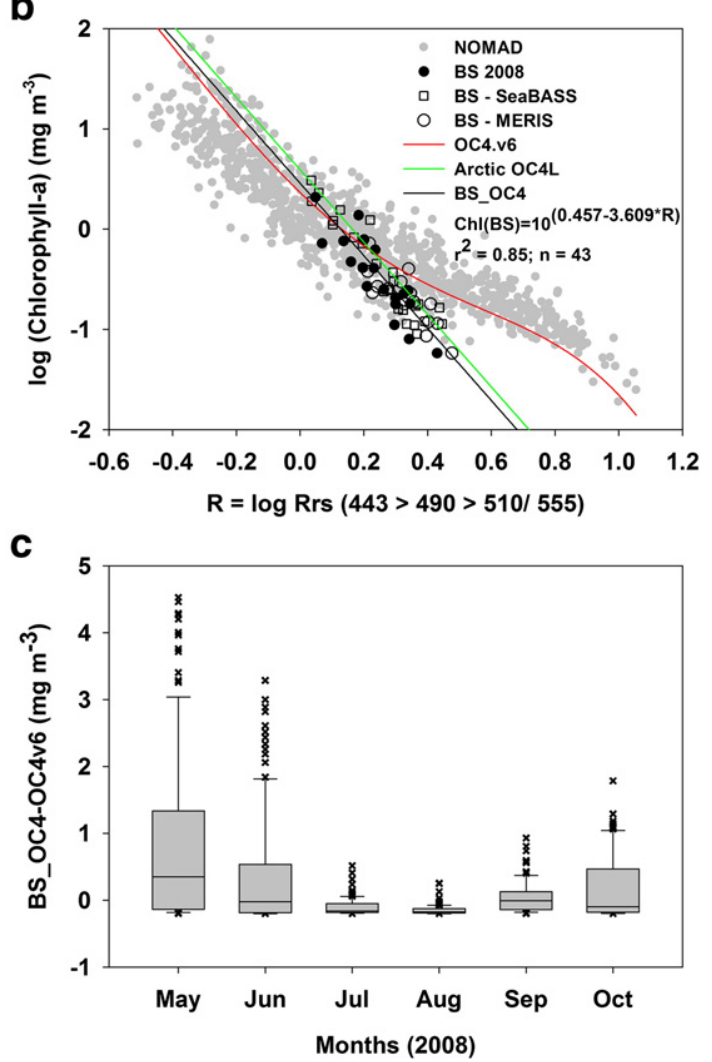

Fig. 9. (a) Comparison of standard NASA chlorophyll-a algorithm (OC4.v6), with in-situ chlorophyll-a. Where Chlorophyll-a is either from in-situ fluorometric measurements (BS08 - black solid circles) (0-5 m average), from MERIS (BS-MERIS - black open circles) obtained during the cruise in July 2008 or from SeaBASS (BS-SeaBASS - black open squares) (Werdell et al., 2003). (b) Comparison of OC4.v6 (red solid line) and Arctic OC4L (Cota et al., 2004) (green solid line) with Bering Sea BS_OC4 (black symbols and solid line). The NOMAD global validation data used in OC4.v6 (gray filled circles) (Werdell \& Bailey, 2005) is also shown. (c) Box-plot of monthly difference between the regional algorithm (BS_OC4) and OC4.v6 applied to MODIS Aqua data for the year 2008 in the study region.

of May-June and the least in July-August (Fig. 9c). The largest difference in May-June is likely due a combination of underestimation and overestimation of chlorophyll-a during the spring bloom and ice melt (CDOM increase), respectively. The slightly larger difference in September-October relative to June-July is likely due to the underestimation of chlorophyll-a during the fall bloom.

From modeled $K_{d}(\lambda)$, we see that there is significant influence of $\mathrm{a}_{\mathrm{CDOM}}(\lambda)$ on $\mathrm{K}_{\mathrm{d}}(\lambda)$ accounting for $>50 \%$ of $\mathrm{K}_{\mathrm{d}}(\lambda)$ at blue wavelengths (Fig. 8c, d). Moreover, the influence of $\mathrm{a}_{\mathrm{CDOM}}(\lambda)$ on $\mathrm{K}_{\mathrm{d}}(\lambda)$ is not uniform through the water column. PP models usually utilize phytoplankton biomass, a photoadaptive variable and some function of sub-surface light field in their formulation (Behrenfeld \& Falkowski, 1997). In vertically integrated PP models, $K_{d}(\lambda)$ is assumed to be constant above the mixed layer depth (MLD) and a function of chlorophyll-a below the MLD with some models including a constant contribution from CDOM throughout the water column (Westberry et al., 2008). Chlorophyll-a is the principal model variable that influences calculation of PP from PP models (Behrenfeld \& Falkowski, 1997). The vertical variability in $K_{d}(\lambda)$ taken together with the error in estimates of chlorophyll-a will result in large errors in the estimation of PP in the study region from satellite data. The Vertically Generalized Production Model (VGPM) (Behrenfeld \& Falkowski, 1997) has been shown to provide good estimates of net primary productivity (NPP) in comparison to measured ${ }^{14} \mathrm{C}$ production in the study region (Lomas et al., 2012). The applicability of the VGPM for retrieval of NPP from satellite data would depend on the accuracy of chlorophyll-a values and description of underwater light field. Apart from these two factors the model would also need to account for the sub-surface chlorophyll maxima observed at most stations in the study region. The precise influence of the bio-optical properties on estimation of PP would require more involved analysis of model variables, which is beyond the scope of this paper. However, it can be concluded unequivocally that the higher CDOM absorption and the lower $\mathrm{a}^{*}{ }_{\mathrm{PHY}}(\lambda)$ if unaccounted for, would greatly influence the estimation of biogeochemical variables from ocean color and the underwater light field in the study region.

\section{Summary and conclusions}

The absorption coefficients showed large variability on the shelf across the coastal, middle and outer domains and were closely tied to distinctive hydrographic and biogeochemical characteristics in each domain. The parameterizations of absorbing coefficients through statistical relationships are strong at all wavelengths examined. Such an approach makes it possible to predict absorption coefficients across the visible domain from a single wavelength and is of great significance in ocean color remote sensing since bio-optical information is usually limited to a few wavelengths. Two main conclusions from this study were (1) lower $\mathrm{a}^{*}{ }_{\mathrm{PHY}}(\lambda)$ was observed relative to middle and lower latitude waters which indicated change in pigment composition and/or package effect, and (2) the relative contribution of $\mathrm{a}_{\mathrm{CDOM}}(\lambda)$ to $\mathrm{a}_{\mathrm{T}}-\mathrm{w}(\lambda)$ was greater than $50 \%$ at all depths and wavelengths (except red wavelengths) for most samples (80\% of the samples). The implications of this are significant to ocean color algorithms where higher than normal CDOM and lower $\mathrm{a}^{*}{ }_{\mathrm{PHY}}(\lambda)$ contribute to errors in estimates of chlorophyll-a. To assess the influence of high $\mathrm{a}_{\text {CDOM }}(\lambda)$ on AOPs, we modeled $\mathrm{R}_{\mathrm{rs}}(\lambda)$ and $\mathrm{K}_{\mathrm{d}}(\lambda)$ using IOPs (absorption (total and total minus $\mathrm{a}_{\mathrm{CDOM}}(\lambda)$ ), and total scattering or backscattering). Good optical closure was observed between modeled and radiometer measured values of $\mathrm{R}_{\mathrm{rs}}(\lambda)$ and $\mathrm{K}_{\mathrm{d}}(\lambda)$. One of the main conclusion of this study was that the standard NASA chlorophyll-a algorithm (OC4.v6) overestimated chlorophyll-a at lower chlorophyll-a concentrations and underestimated chlorophyll-a at higher chlorophyll-a concentrations; the Arctic OC4L was similar to the algorithm developed in this study. The $\mathrm{a}_{\mathrm{CDOM}}(\lambda)$ had a significant influence on $\mathrm{K}_{\mathrm{d}}(\lambda)$ accounting for $>50 \%$ of $K_{d}(\lambda)$ at blue wavelengths which was variable with depth. The error in the estimation of chlorophyll-a along with vertical variability of $K_{d}(\lambda)$ would introduce large biases in estimates of PP, which is essential for understanding changes occurring in the Bering Sea ecosystem in the long term. A cautious approach must be utilized while considering the results from this study as they may not be applicable to other regions or the same regions in different seasons and are valid only over the chlorophyll-a range of this study.

The present study provides important insight for improving ocean color algorithms and bio-optical models as well as for more accurate retrieval of absorbing coefficients in the southeastern Bering Sea. 


\section{Acknowledgments}

This study was funded by NASA grant No: NNX07AR15G and NNX10AP10G. The authors would like to thank Dr. Ray Sambrotto for the opportunity to participate in the BEST funded research cruise on the USCGC Healy and NASA's Ocean Color group for access to SeaBASS and ocean color data.

\section{References}

Aas, E. (1987). Two-stream irradiance model for deep waters. Applied Optics, 26, 2095-2101. http://dx.doi.org/10.1364/AO.26.002095.

Aguilar-Islas, A. M., Rember, R. D., Mordy, C. W., \& Wu, J. (2008). Sea ice-derived dissolved iron and its potential influence on the spring algal bloom in the Bering Sea. Geophysical Research Letters, 35, L24601. http://dx.doi.org/10.1029/2008gl035736.

Babin, M., Stramski, D., Ferrari, G. M., Claustre, H., Bricaud, A., Obolensky, G., et al. (2003). Variations in the light absorption coefficients of phytoplankton, nonalgal particles, and dissolved organic matter in coastal waters around Europe. Journal of Geophysical Research, 108, 3211. http://dx.doi.org/10.1029/2001jc000882.

Bannister, T. (1974). Production equations in terms of chlorophyll concentration, quantum yield, and upper limit to production. Limnology and Oceanography, 19, 1-12.

Barnard, A. H., Pegau, W. S., \& Zaneveld, J. R. V. (1998). Global relationships of the inherent optical properties of the oceans. Journal of Geophysical Research, 103, 24955-24968. http://dx.doi.org/10.1029/98jc01851.

Behrenfeld, M. J., \& Falkowski, P. G. (1997). A consumer's guide to phytoplankton primary productivity models. Limnology and Oceanography, 42, 1479-1491. http://dx.doi.org/ 10.1016/S1054-3139(02)00280-1.

Belanger, S., Xie, H. X., Krotkov, N., Larouche, P., Vincent, W. F., \& Babin, M. (2006). Photomineralization of terrigenous dissolved organic matter in Arctic coastal waters from 1979 to 2003: Interannual variability and implications of climate change. Global Biogeochemical Cycles, 20, GB4005. http://dx doi.org/10.1029/2006gb002708.

Boss, E., Pegau, W. S., Lee, M., Twardowski, M., Shybanov, E., Korotaev, G., et al. (2004). Particulate backscattering ratio at LEO 15 and its use to study particle composition and distribution. Journal of Geophysical Research, 109, C01014. http://dx.doi.org/ 10.1029/2002jc001514.

Bricaud, A., Babin, M., Morel, A., \& Claustre, H. (1995). Variability in the chlorophyllspecific absorption-coefficients of natural phytoplankton - analysis and parameterization. Journal of Geophysical Research, 100, 13321-13332. http://dx.doi.org/ 10.1029/95JC00463.

Bricaud, A., Claustre, H., Ras, J., \& Oubelkheir, K. (2004). Natural variability of phytoplanktonic absorption in oceanic waters: Influence of the size structure of algal populations. Journal of Geophysical Research, 109, C11010. http://dx.doi.org/ 10.1029/2004jc002419.

Bricaud, A., Morel, A., Babin, M., Allali, K., \& Claustre, H. (1998). Variations of light absorption by suspended particles with chlorophyll a concentration in oceanic (case 1) waters: Analysis and implications for bio-optical models. Journal of Geophysical Research, 103, 31033-31044. http://dx.doi.org/10.1029/98JC02712.

Bricaud, A., \& Stramski, D. (1990). Spectral absorption coefficients of living phytoplankton and nonalgal biogenous matter - a comparison between the Peru upwelling area and the Sargasso Sea. Limnology and Oceanography, 35, 562-582.

Brown, C. A., Huot, Y., Werdell, P. J., Gentili, B., \& Claustre, H. (2008). The origin and global distribution of second order variability in satellite ocean color and its potential applications to algorithm development. Remote Sensing of Environment, 112, 4186-4203. http://dx.doi.org/10.1016/j.rse.2008.06.008.

Ciotti, A. M., Lewis, M. R., \& Cullen, J. J. (2002). Assessment of the relationships between dominant cell size in natural phytoplankton communities and the spectral shape of the absorption coefficient. Limnology and Oceanography, 47, 404-417. http://dx.doi.org/10.2307/3068986.

Cleveland, J. S. (1995). Regional models for phytoplankton absorption as a function of chlorophyll-a concentration. Journal of Geophysical Research, 100, 13333-13344. http://dx.doi.org/10.1029/95JC00532.

Cleveland, J. S., \& Weidemann, A. D. (1993). Quantifying absorption by aquatic particles: A multiple scattering correction for glass-fiber filters. Limnology and Oceanography, 38, 1321-1327.

Coachman, L. K. (1986). Circulation, water masses, and fluxes on the southeastern Bering Sea shelf. Continental Shelf Research, 5, 23-108. http://dx.doi.org/10.1016/02784343(86)90011-7.

Cota, G. F., Harrison, W. G., Platt, T., Sathyendranath, S., \& Stuart, V. (2003). Bio-optical properties of the Labrador Sea. Journal of Geophysical Research, 108, 3228. http://dx.doi.org/ 10.1029/2000jc000597.

Cota, G. F., Wang, H., \& Comiso, J. C. (2004). Transformation of global satellite chlorophyll retrievals with a regionally tuned algorithm. Remote Sensing of Environment, 90, 373-377. http://dx.doi.org/10.1016/j.rse.2004.01.005.

D'Sa, E. J., Steward, R. G., Vodacek, A., Blough, N. V., \& Phinney, D. (1999). Determining optical absorption of colored dissolved organic matter in seawater with a liquid capillary waveguide. Limnology and Oceanography, 44, 1142-1148. http://dx.doi.org/ 10.4319/lo.1999.44.4.1142

Duysens, L. N. M. (1956). The flattening of the absorption spectrum of suspensions, as compared to that of solutions. Biochimica et Biophysica Acta, 19, 1-12. http://dx.doi.org/ 10.1016/0006-3002(56)90380-8

Feely, R. A., Massoth, G. J., \& Paulson, A. J. (1981). The distribution and elemental composition of suspended particulate matter in Norton Sound and the northeastern Bering Sea shelf: Implications for $\mathrm{Mn}$ and $\mathrm{Zn}$ recycling in coastal waters. In
D. W. Hood, \& J. A. Calder (Eds.), The Eastern Bering Sea Shelf: Oceanography and resourcesWashington, D. C.: U. S. Dept. of Commerce, National Oceanic and Atmospheric Administration, Office of Marine Pollution Assessment Washington, D. C..

Gordon, H. R., Brown, O. B., Evans, R. H., Brown, J. W., Smith, R. C., Baker, K. S., et al. (1988). A semianalytic radiance model of ocean color. Journal of Geophysical Research, 93, 10909-10924. http://dx.doi.org/10.1029/JD093iD09p10909.

Gould, R. W., Arnone, R. A., \& Martinolich, P. M. (1999). Spectral dependence of the scattering coefficient in case 1 and case 2 waters. Applied Optics, 38, 2377-2383. http://dx.doi.org/10.1364/ao.38.002377.

Grebmeier, J. M., Overland, J. E., Moore, S. E., Farley, E. V., Carmack, E. C., Cooper, L. W. et al. (2006). A major ecosystem shift in the Northern Bering Sea. Science, 311, 1461-1464. http://dx.doi.org/10.1126/science.1121365.

Helbling, E. W., Chalker, B. E., Dunlap, W. C., HolmHansen, O., \& Villafane, V. E. (1996) Photoacclimation of Antarctic marine diatoms to solar ultraviolet radiation. Journal of Experimental Marine Biology and Ecology, 204, 85-101. http://dx.doi.org/10.1016/ 0022-0981(96)02591-9.

Holm-Hansen, O., Lorenzen, C. J., Holmes, R. W., \& Strickland, J. D. H. (1965). Fluorometric determination of chlorophyll. Journal du Conseil. Conseil permanent international pour l'exploration de la mer, 30, 3-15. http://dx.doi.org/10.1093/icesjms/30.1.3.

Kachel, N. B., Hunt, G. L., Salo, S. A., Schumacher, J. D., Stabeno, P. J., \& Whitledge, T. E. (2002). Characteristics and variability of the inner front of the southeastern Bering Sea. Deep Sea Research Part II: Topical Studies in Oceanography, 49, 5889-5909. http://dx.doi.org/10.1016/S0967-0645(02)00324-7.

Kirk, J. T. O. (1994). Light and photosynthesis in aquatic ecosystems (2nd ed.). New York: Cambridge University Press.

Kishino, M., Takahashi, M., Okami, N., \& Ichimura, S. (1985). Estimation of the spectral absorption-coefficients of phytoplankton in the sea. Bulletin of Marine Science, 37, 634-642.

Laurion, I., Lami, A., \& Sommaruga, R. (2002). Distribution of mycosporine-like amino acids and photoprotective carotenoids among freshwater phytoplankton assemblages. Aquatic Microbial Ecology, 26, 283-294. http://dx.doi.org/10.3354/ame026283.

Lee, Z. P., Carder, K. L., \& Arnone, R. A. (2002). Deriving inherent optical properties from water color: A multiband quasi-analytical algorithm for optically deep waters. Applied Optics, 41, 5755-5772. http://dx.doi.org/10.1364/AO.41.005755.

Lomas, M. W., Moran, S. B., Casey, J. R., Bell, D. W., Tiahlo, M., Whitefield, J., et al. (2012). Spatial and seasonal variability of primary production on the Eastern Bering Sea shelf. Deep Sea Research Part II: Topical Studies in Oceanography, 65-70, 126-140. http://dx.doi.org/10.1016/j.dsr2.2012.02.010.

Mathis, J. T., Cross, J. N., Bates, N. R., Moran, S. B., Lomas, M. W., Mordy, C. W., et al. (2010). Seasonal distribution of dissolved inorganic carbon and net community production on the Bering Sea shelf. Biogeosciences, 7, 1769-1787. http://dx.doi.org/ 10.5194/bg-7-1769-2010.

Matsuoka, A., Hill, V., Huot, Y., Babin, M., \& Bricaud, A. (2011). Seasonal variability in the light absorption properties of western Arctic waters: Parameterization of the individual components of absorption for ocean color applications. Journal of Geophysical Research, 116, C02007. http://dx.doi.org/10.1029/2009jc005594.

Matsuoka, A., Huot, Y., Shimada, K., Saitoh, S. I., \& Babin, M. (2007). Bio-optical characteristics of the western Arctic Ocean: Implications for ocean color algorithms. Canadian Journal of Remote Sensing, 33, 503-518.

Maynard, N. G., \& Clark, D. K. (1987). Satellite color observations of spring blooming in Bering Sea shelf waters during the ice edge retreat in 1980. Journal of Geophysical Research, 92, 7127-7139. http://dx.doi.org/10.1029/JC092iC07p07127.

McClain, C. R. (2009). A decade of satellite ocean color observations. Annual Review of Marine Science, 1, 19-42. http://dx.doi.org/10.1146/annurev.marine.010908.163650.

Mitchell, B. G. (1990). Algorithms for determining the absorption coefficients for aquatic particulates using the quantitative filter technique. Ocean Optics X (pp. 137-148). SPIE.

Mitchell, B. G., \& Holm-Hansen, O. (1991). Bio-optical properties of Antarctic Peninsula waters - differentiation from temperate ocean models. Deep Sea Research Part I: Oceanographic Research Papers, 38, 1009-1028. http://dx.doi.org/10.1016/01980149(91)90094-V.

Mitchell, B. G., Kahru, M., Wieland, J. \& Stramska, M. (2003). Determination of spectral absorption coefficients of particles, dissolved materials and phytoplankton for discrete water samples. Ocean Optics Protocols For Satellite Ocean Color Sensor Validation, Revision 4, Volume 4: Inherent optical properties: instruments, characterization, field measurements and data analysis protocols.. Greenbelt, Maryland: NASA Techecnicla Report.

Mobley, C. D. (1994). Light and water: Radiative transfer in natural waters. Academic Press.

Moisan, T. A., \& Mitchell, B. G. (1999). Photophysiological acclimation of Phaeocystis antarctica Karsten under light limitation. Limnology and Oceanography, 247-258. http://dx.doi.org/10.4319/lo.1999.44.2.0247.

Moore, L., Goericke, R., \& Chisholm, S. (1995). Comparative physiology of Synechococcus and Prochlorococcus: Influence of light and temperature on growth, pigments, fluorescence and absorptive properties. Marine Ecology Progress Series, 116, 259-275. http://dx.doi.org/10.3354/meps116259.

Moran, S. B., Lomas, M. W., Kelly, R. P., Gradinger, R., Iken, K., \& Mathis, J. T. (2012). Seasonal succession of net primary productivity, particulate organic carbon export, and autotrophic community composition in the eastern Bering Sea. Deep Sea Research Part II: Topical Studies in Oceanography, 65-70, 84-97. http://dx.doi.org/ 10.1016/j.dsr2.2012.02.011

Mordy, C. W., Cokelet, E. D., Ladd, C., Menzia, F. A., Proctor, P., Stabeno, P. J., et al. (2012). Net community production on the middle shelf of the eastern Bering Sea. Deep Sea Research Part II: Topical Studies in Oceanography, 65-70, 110-125. http://dx.doi.org/10.1016/j.dsr2.2012.02.012.

Morel, A., \& Bricaud, A. (1981). Theoretical results concerning light absorption in a discrete medium, and application to specific absorption of phytoplankton. Deep Sea 
Research Part I: Oceanographic Research Papers, 28, 1375-1393. http://dx.doi.org/ 10.1016/0198-0149(81)90039-X.

Morel, A., \& Maritorena, S. (2001). Bio-optical properties of oceanic waters: A reappraisal. Journal of Geophysical Research, 106, 7163-7180. http://dx.doi.org/10.1029/ 2000JC000319.

Mueller, J. L., \& Austin, R. W. (1995). Ocean optics protocols for SeaWiFS validation. In S. B. Hooker, E. R. Firestone, \& J. G. Acker (Eds.), SeaWiFS Technical Report Series (pp. 67). Greenbelt, Maryland: NASA Goddard Space Flight Center.

Müller-Karger, F. E., McClain, C. R., Sambrotto, R. N., \& Ray, G. C. (1990). A comparison of ship and coastal zone color scanner mapped distribution of phytoplankton in the southeastern Bering Sea. Journal of Geophysical Research, 95, 11483-11499. http://dx.doi.org/10.1029/JC095iC07p11483.

Naik, P., \& D'Sa, E. J. (2012). Phytoplankton light absorption of cultures and natura samples: Comparisons using two spectrophotometers. Optics Express, 20, 4871-4886. http://dx.doi.org/10.1364/OE.20.004871.

Naik, P., D'Sa, E. J., Goes, J. I., \& Gomes, H. R. (2010). Assessment of particulate absorption properties in the southeastern Bering Sea from in-situ and remote sensing data. Journal of Applied Remote Sensing, 4. http://dx.doi.org/10.1117/1.3525572 (043561-043561-043520).

O'Reilly, J. E., Maritorena, S., Mitchell, B. G., Siegel, D. A., Carder, K. L., Garver, S. A., et al (1998). Ocean color chlorophyll algorithms for SeaWiFS. Journal of Geophysical Research, 103, 24937-24953. http://dx.doi.org/10.1029/98jc02160.

Pegau, W. S., Gray, D., \& Zaneveld, J. R. V. (1997). Absorption and attenuation of visible and near-infrared light in water: Dependence on temperature and salinity. Applied Optics, 36, 6035-6046. http://dx.doi.org/10.1364/ao.36.006035.

Riegger, L., \& Robinson, D. (1997). Photoinduction of UV-absorbing compounds in Antarctic diatoms and Phaeocystis antarctica. Marine Ecology Progress Series, 160 13-25. http://dx.doi.org/10.3354/meps160013.

Schallenberg C. Lewis, M. R. Kelley, D. E \& Cullen, J. J. (2008). Inferred influence of nutrient availability on the relationship between Sun-induced chlorophyll fluorescence and incident irradiance in the Bering Sea. Journal of Geophysical Research, 113, C07046. http://dx.doi.org/10.1029/2007jc004355.

Schumacher, J. D., \& Stabeno, P. J. (1998). The continental shelf of the Bering Sea. New York, NY: John Wiley and Sons, Inc.

Siegel, D. A., Maritorena, S., Nelson, N. B., \& Behrenfeld, M. J. (2005). Independence and interdependencies among global ocean color properties: Reassessing the bio-optical assumption. Journal of Geophysical Research, 110, C07011. http://dx.doi.org/ 10.1029/2004jc002527.

Sigler, M. F., Harvey, H. R., Ashjian, C. J., Lomas, M. W., Napp, J. M., Stabeno, P. J., et al. (2010). How does climate change affect the Bering Sea ecosystem? EOS. Transactions of the American Geophysical Union, 91, 457. http://dx.doi.org/10.1029/2010E0480001.

Sosik, H. M., Vernet, M., \& Mitchell, A. D. (1992). A comparison of particulate absorption properties between high- and mid-latitude surface waters. Antarctic Journal of the United States, 27, 162-164. http://dx.doi.org/10.1016/0967-0637(95)00081-G.
Stabeno, P. J., Farley, E. V., Jr., Kachel, N. B., Moore, S., Mordy, C. W., Napp, J. M., et al (2012). A comparison of the physics of the northern and southern shelves of the eastern Bering Sea and some implications for the ecosystem. Deep Sea Research Part II: Topical Studies in Oceanography, 65-70, 14-30. http://dx.doi.org/10.1016/ j.dsr2.2012.02.019.

Stabeno, P. J., Hunt, J. G. L., Napp, J. M., \& Schumacher, J. D. (2006). Physical forcing of ecosystem dynamics on the Bering Sea shelf. Cambridge, MA: Harvard University Press.

Stabeno, P. J., Kachel, N. B., Moore, S. E., Napp, J. M., Sigler, M., Yamaguchi, A., et al. (2012). Comparison of warm and cold years on the southeastern Bering Sea shelf and some implications for the ecosystem. Deep Sea Research Part II: Topical Studies in Oceanography, 65-70, 31-45. http://dx.doi.org/10.1016/j.dsr2.2012.02.020.

Stabeno, P. J., Kachel, N., Mordy, C., Righi, D., \& Salo, S. (2008). An examination of the physical variability around the Pribilof Islands in 2004. Deep Sea Research Part It: Topical Studies in Oceanography, 55, 1701-1716. http://dx.doi.org/10.1016/ j.dsr2.2008.03.006.

Stramska, M., Stramski, D., Kaczmarek, S., Allison, D. B., \& Schwarz, J. (2006). Seasonal and regional differentiation of bio-optical properties within the north polar Atlantic. Journa of Geophysical Research, 111, C08003. http://dx.doi.org/10.1029/2005jc003293.

Stramski, D., \& Morel, A. (1990). Optical properties of photosynthetic picoplankton in different physiological states as affected by growth irradiance. Deep Sea Research Part I: Oceanographic Research Papers, 37, 245-266. http://dx.doi.org/10.1016/ 0198-0149(90)90126-G.

Twardowski, M. S. Boss, E Sullivan, J. M. \& Donaghay, P. L (2004). Modeling the spectra shape of absorption by chromophoric dissolved organic matter. Marine Chemistry, 89 , 69-88. http://dx.doi.org/10.1016/j.marchem.2004.02.008.

Wang, J., Cota, G. F., \& Ruble, D. A. (2005). Absorption and backscattering in the Beaufort and Chukchi Seas. Journal of Geophysical Research, 110, C04014. http://dx.doi.org 10.1029/2002jc001653.

Werdell, P. J., \& Bailey, S. W. (2005). An improved in-situ bio-optical data set for ocean color algorithm development and satellite data product validation. Remote Sensing of Environment, 98, 122-140. http://dx.doi.org/10.1016/j.rse.2005.07.001.

Werdell, P. J., Bailey, S., Fargion, G., Pietras, C., Knobelspiesse, K., Feldman, G., et al. (2003). Unique data repository facilitates ocean color satellite validation. EOS Transactions of the American Geophysical Union, 84. http://dx.doi.org/10.1029/ 2003eo380001.

Westberry, T., Behrenfeld, M. J., Siegel, D. A., \& Boss, E. (2008). Carbon-based primary productivity modeling with vertically resolved photoacclimation. Global Biogeochemical Cycles, 22, GB2024. http://dx.doi.org/10.1029/2007gb003078.

Zaneveld, J. R. V., Kitchen, J. C., \& Moore, C. C. (1994). Scattering error correction of reflecting-tube absorption meters. Ocean Optics XII (pp. 44-55). Bergen, Norway: SPIE. 